\title{
Karayoluyla Yapılan Eşya Taşımalarında Taşıyıcının TTK m. 886 Kapsamında Pervasızca ve Zararın Muhtemelen Meydana Geleceği Bilinciyle Davranışı
}

\author{
The Carrier's Behaviour Recklessly and with Knowledge that Damage \\ Would Probably Result within the Scope of Art. 886 TCC in Carriage of \\ Goods by Road
}

Esra Kaşak* iD

\section{öz}

Taşıyıcı, eşyanın taşınmak üzere teslim alınmasından teslim edilmesine kadar geçecek süre içinde, eşyanın zıyaından, hasarından veya teslimindeki gecikmeden doğan zararlardan sorumludur. Taşıma hukukunda, taşıyıcının tazminat sorumluluğu prensip olarak belirli bir tutar ile sınırlandırılmıştır. Ancak TTK m. 886'ya göre taşıyıcı; zarara, kasten veya pervasızca ve bir zararın muhtemelen meydana geleceği bilinciyle sebep olursa, sorumluluk sinırlamalarından yararlanamaz. Kasıt hem dolaylı hem de doğrudan kastı kapsar. Pervasızca ve bir zararın muhtemelen meydana geleceği bilinciyle davranış ise, olası kasıt ağırlığına ulaşmayan bir kusurdur ve yeni bir bilinçli ağır ihmal türüdür. CMR m. 29'da ifadesini bulan kasta eş değer kusur derecesinin belirlenmesi bakımından da TTK m. 886'da yer alan pervasızca davranış kusurunun esas alınması gerekir. Çalışma ile bu yeni kusur türünün içeriği ve geleneksel kusur dereceleri arasındaki yerinin belirlenmesi amaçlanmıştır.

Anahtar Kelimeler: TTK m. 886, Kasıt, Pervasızca Davranış, Zararın Muhtemelen Meydana Geleceği Bilinci, CMR m. 29.

\section{ABSTRACT}

The carrier is responsible for loss, damage or delay in delivery of the goods during the period from the receipt of the goods for carriage to their delivery. In transport law, the responsibility of the carrier for compensation is in principle limited to a certain amount. However, according to Art. 886 Turkish Commercial Code (TCC), if the damage is done with intent to cause damage or recklessly and with knowledge that damage would probably result, then the carrier will not be able to benefit from the limitations of responsibility. Intention encompasses both indirect (dolus eventualis) and direct intention (dolus directus). Reckless and with knowledge that damage would probably result, is a fault that does not reach indirect intention (dolus eventualis) and is a new type of advertent gross negligence. In order to determine the degree of fault equivalent to wilful misconduct regulated in Art. 29 CMR, recklessly behaviour fault stipulated in Art. 886 TCC should be taken as basis. The study aims to determine the content of this new fault type and its position among the traditional fault types.

Keywords: Art. 886 TCC, Intention, Recklessly Behaviour, Knowledge that Damage Would Probably Result, Art. 29 CMR.

* Dr. Öğr. Üyesi, Ankara Hacı Bayram Veli Üniversitesi, Hukuk Fakültesi, Ticaret Hukuku Anabilim Dalı, ORCID: 00000001-8294-4408. 


\section{TTK M. 886 HÜKMÜNÜN IÇERIĞi VE işLEVi}

Taşıyıcının, eşyanın zıyaından, hasarından veya teslimindeki gecikmeden doğan zararlardan sorumlu olduğuna ilişkin temel kural Türk Ticaret Kanunu (TTK) ${ }^{1}$ m. 875/1'de yer almaktadır. Her taşıma türünde görüldüğü üzere, karayoluyla eşya taşımalarında da taşıyıcının sorumluluğunu gerektiren zararlar bakımından tazminat yükümlülüğünün belirli bir miktarla sınırlandırılması esası kabul edilmiştir (TTK m. 882, 885)². Ancak zarara kasten sebep olunması halinde sınırlı sorumluluk imtiyazından yararlanılamayacağına ilişkin Roma hukukuna kadar dayanan temel düşünce (fraus omnia corrumpit) ${ }^{3}$, TTK m. 886'da taşıyıcının bazı davranışları bakımından karşılı̆̆ını bulmuştur. Hükmün lafzına göre zarara, 'kasten' veya 'pervasızca bir davranışla ve böyle bir zararın meydana gelmesi ihtimalinin bilinciyle işlenmiş bir fiilinin veya ihmalinin' sebebiyet verdiği ispat edilen taşıyıcı veya TTK m. 879'da belirtilen yardımcıları ${ }^{4}$, sorumluluk sınırlamalarından yararlanamaz ${ }^{5}$.

TTK m. 886, taşıma işleri komisyoncusunun (TTK m. 928) ve taşınma eşyası taşımalarında da taşıyıcının sorumluluğu (TTK m. 894, karşılaştırınız m. 901) bakımından uygulama alanı bulan bir düzenlemedir ${ }^{6}$. Taşıyıcının yardımcılarından birine karşı ileri sürülen sözleşme dışı sorumluluktan doğan istemler bakımından da aynı esas geçerlidir (TTK m. 887). Kanun’un öngördüğü iki nitelikli kusur halinden birinin, daha açık anlatımla «kasıt» veya kısaca «pervasızca davranış kusurunun» mevcudiyeti halinde, TTK m. 855/1 ve TTK m. 930/1'de öngörülen bir yıllık zamanaşımı süreleri üç yıla uzar (TTK m. 855/5, 930/2). Bu açıdan TTK m. 886; bir yandan sınırlı sorumluluk hükümlerinden istifade imkânını ortadan kaldırması, diğer yandan zamanaşımı sürelerinin uzamasına yol açması bakımından oldukça geniş bir uygulama alanına sahiptir.

\section{CMR M. 29 BAKIMINDAN TTK M. 886'NIN ÖNEMİ}

Taşıyıcının sınırlı sorumluluktan yararlanma hakkının kaybına yol açan kusur türlerini gösteren TTK m. 886’nın bir diğer önemi ‘Eşyaların Karayolundan Uluslararası Nakliyatı İçin Mukavele Sözleşmesi

1 Türk Ticaret Kanunu, Kanun Numarası: 4721, Kabul Tarihi: 13.01.2011, RG 14.02.2011/27846.

2 Bu konuda ve sorumluluk sınırlarının belirlenmesine ilişkin tarihi süreç hakkında bakınız (bkz) Mertol Can, Türk Taşıma Hukukunun Genel Esasları Cilt I (1. Bası, İmaj 2017) 97; Burak Adıgüzel, Taşıma Hukuku Deniz Ticareti Hariç (3. Bası, Adalet 2020) 216 vd. Denizde eşya taşımaları bakımından taşıyanın sorumluluğunun sınırlandırılmasına ilişkin uluslararası sözleşmeler hakkında kronolojik bir inceleme, ulusal düzenlemeler ve sınırlı sorumluluğun getirilme gerekçeleri, sınırlandırmanın kimin menfaatine olduğu ve bunlara ilişkin olarak Yazar'ın eleştiri ve değerlendirmelerini de içeren ayrıntılı bir inceleme için bkz Cüneyt Süzel, Navlun Sözleşmesinden Doğan Sorumluluğun Sınırlandırılması (1. Baskı, On İki Levha 2021) 5 vd; ayrıca bkz Duygu Damar, 'Die „Costa Concordia“ ist auf den Felsen aufgelaufen - auch das Recht auf Haftungsbeschränkung?' (2012) 8 Verbraucher und Recht-Zeitschrift für Wirtschafts - und Verbraucherrecht 287, 291.

3 Helga Jesser-Huß, 'CMR Art. 29' in Karsten Schmidt (ed), Münchener Kommentar zum Handelsgesetzbuch Band 7 (4th edn, C.H.BECK 2020) CMR Art. 29 N 1.

4 Taşıyıcının yardımcıları hakkında bkz Burak Adıgüzel, 'Eşya Taşımalarında Taşıyıcı Yardımcısı Kavramı ve Yardımcıların Taşıyıcının Sorumluluğuna Etkisi' (2008) 3(2) Erzincan Üniversitesi Hukuk Fakültesi Dergisi 291, 291 vd.

5 Şükrü Yıldız, 'TTK Hükümleri Işığında Taşıyıcının (Kara Yoluyla) Eşya Taşımadan Doğan Sorumluluğu' (2015/2) 14(28) İstanbul Ticaret Üniversitesi Sosyal Bilimler Dergisi 97, 107 vd.

6 Adıgüzel, Taşıma (n 2) 267, 315; Orhan Sekmen, TKHK Kapsamında Karayoluyla Eşya Taşımasında Zıya, Hasar ve Gecikmeden Doğan Tazminat (1. Bası, Aristo 2020) 28. 
$(C M R)^{37}$ m. 29/1 bakımından ortaya çıkmaktadır. CMR, karayoluyla yapılan uluslararası eşya taşıma sözleşmeleri kapsamında ortaya çıkan uyuşmazlıklarda, asgari bir uygulama birliği sağlanmasını amaçlamaktadır. Bununla birlikte, CMR'de tüm konular tam ve kapsamlı bir şekilde hükme bağlanmamışs; ; aksine Sözleşme’de bazı boşluklar bırakılmıştır ${ }^{9}$. Anılan sebeple CMR bakımından bazı hallerde milli hukuklar da tamamlayıcı olarak uygulama alanı bulmaktadır ${ }^{10}$. Sözleşme’nin işbu çalışma bakımından önem taşıyan 29. maddesinde yer alan 'kasta eş değer kusur' kavramının belirlenmesinde, davaya bakan mahkemenin milli hukukuna (lex fori) atıf yapılmıştır ${ }^{11}$. Bu sebeple kasta eş değer kusurun ne anlama geldiği konusunda ülkeden ülkeye değișen uygulamaların ortaya çıkması sonucu doğmuştur ${ }^{12}$.

CMR'de taşıyıcının, eşyayı teslim aldığı andan teslim edinceye kadar, bunun zıyaından, hasarından veya teslimindeki gecikmeden doğan zararlardan sorumlu olacağı esası benimsenmiştir. CMR’nin 29. maddesinde, zarara kasten veya kasta eş değer kusurlu bir davranışla sebep olan taşıyıcının ${ }^{13}$, sorumluluğunu kaldıran, sınırlayan veya ispat yükünü karşı tarafa yükleyen dördüncü bölüm ${ }^{14}$ hükümlerinden ${ }^{15}$ yararlanamayacağı kabul edilmiştir. Taşıyıcının kastı veya kasta eş değer kusuru, ayrıca zamanaşımı sürelerinin de uzamasına yol açmaktadır (CMR m. 32).

7 Türkiye Cumhuriyeti’nin 7.12.1993 tarih ve 3939 sayılı Kanun'la uygun bulunan (RG 14.12.1993/21788) 'Eşyaların Karayolundan Uluslararası Nakliyatı için Mukavele Sözleşmesi (CMR)' ile bu Sözleşme’ye ek 5.7.1978 tarihli Protokol'e, Sözleşmenin 47. maddesine ihtirazi kayıt konmak suretiyle katılması Bakanlar Kurulunca 2.12.1994 tarihinde kararlaştırılmıştır (RG 04.01.1995/22161).

8 Reto Sutter, 'Besteht eine Darlegungspflicht des angegriffenen Frachtführers beim Verschuldensnachweis? Betrachtungen zum internationalen und schweizerischen Frachtrecht' (2010) 3 Aktuelle Juristische Praxis 325, 325.

9 Barbara Klett, 'Die Haftung im internationalen Strassengüterverkehr nach CMR' (2017) 1 Strassenverkehr 20, 23; Sutter (n 8) 325 .

10 Sutter (n 8) 325.

11 Jürgen Basedow, 'Internationales Einheitsprivatrecht im Zeitalter der Globalisierung', (2017) 81 Rabels Zeitschrift für ausländisches und internationales Privatrecht 1, 23 dipnot 114; Jesser-Huß (n 3) CMR Art. 29 N 6.

12 Aksoy Yavaş, 'Kara Yolunda Yapılan Yük Taşımasında Sınırlı Sorumluluktan Yararlanma Hakkının Kaybına Sebebiyet Veren Kusur Türlerinin Değerlendirilmesi' (2017) 2(Ocak) Yeditepe Üniversitesi Hukuk Fakültesi Dergisi 200, 209; Kübra Yetiş Şamlı, Uluslararası Kara, Hava ve Deniz Yoluyla Eşya Taşımalarında Taşıyıcının/Taşıyanın Sınırlı Sorumluluktan Yararlanma Hakkının Kaybı (1. Bası, On İki Levha 2008) 33. Bu hususta ayrıca bkz Krijn Haak, 'Haftungsbegrenzung und ihre Durchbrechung nach der CMR in den Niederlanden' (2004) 3 Transportrecht 104, 104.

13 CMR m. 29'un alternatif çevirisi için bkz Abuzer Kendigelen ve Alihan Aydın, 'Karayolu ile Uluslararası Eşya Taşıma Sözleșmesine İlişkin Antlaşma (CMR), Resmi Çeviriye İlișkin Sorunlar ve Bir Serbest Çeviri Denemesi' iç Hayri Domaniç, Oğuz İmregün, Erdoğan Moroğlu ve Abuzer Kendigelen (edr), Prof. Dr. Ömer Teomania 55. Yaş Günü Armağanı Cilt 1 (Beta 2002) 515. Resmi Gazetede kasta eş değer kusurun 'isteyerek kötü harekete eşdeğer sayılan kusur' şeklindeki çevirisinin eleştirisi için bkz Burak Adıgüzel, 'Yargıtay Kararlarında CMR m. 29'daki Kasta Eşdeğer Kusur Kavramının Yorumlanması' iç Başak Şit (ed), Ticaret Hukuku ve Yargıtay Kararları Sempozyumu XXIV 10-11 Aralık (Banka ve Ticaret Hukuku Enstitüsü 2010) 353, 355.

14 Sözleşme’nin resmi çevirisinde 'bu madde' denilmişse de doğrusu 'bu bölüm' olmalıdır. Bkz Alihan Aydın, CMR'ye Göre Taşıyıcının Zıya, Hasar ve Gecikmeden Doğan Sorumluluğu (1. Bası, Arıkan 2006) 173.

15 İlgili hükümler hakkında bkz ve karşılaştırınız (karş) Karsten Otte, 'CMR Art. 29' in Franco Ferrari, Eva-Maria Kieninger, Peter Mankowski, Karsten Otte, Ingo Saenger, Götz Schulze und Ansgar Staudinger (eds), Internationales Vertragsrecht (3rd edn, C.H.BECK 2018) CMR Art. 29 N 2; Mirina Grosz and Alexander von Ziegler 'CMR Art. 29' in Willi Fischer and Thierry Luterbacher (eds), Haftpflichtkommentar Kommentar zu den schweizerischen Haftpflichtbestimmungen (1st edn, Dike 2016) CMR Art. 29 N 37. 
Milli hukuka yapılan atıf neticesinde, örneğin Avusturya ${ }^{16}$, İsviçre ${ }^{17}$, Polonya ${ }^{18}$, İtalya ${ }^{19}$ ve İskandinav ülkelerinde ${ }^{20}$ kasta eş değer kusurun 'ağır ihmal' olduğu kabul edilmiştir Alman hukuku bakımından ise meseleyi 1.7.1998 tarihinde yürürlüğe giren Taşıma Hukuku Revizyon Kanunu ${ }^{21}$ öncesi ve sonrası şeklinde ikiye ayırarak incelemek gerekir. Anılan revizyona kadar kasta eş değer kusur, Alman hukukunda 'ağır ihmal' olarak nitelendirilmiştir ${ }^{22}$. Revizyondan sonra ise CMR m. 29 bakımından kasta eş değer kusurun belirlenmesinde, Alman Ticaret Kanunu (AlmTK) ${ }^{23} \$ 435$ ’te öngörülen pervasızca davranış kusuru dikkate alınmaktadır ${ }^{24}$. Bahis konusu kusur derecesi ile sınırsız sorumluluğun şartlarının ağır ihmale nazaran ağırlaştırıldığı konusunda Alman hukukunda yaygın bir kanaat bulunmaktadır ${ }^{25}$.

Türk mahkemelerinde görülen ve CMR kapsamında kalan taşıma sözleşmelerinden doğan uyuşmazlıklarda kasta eş değer kusur kavramı, TTK m. 886'da hükme bağlanan 'pervasızca davranış kusuru' ölçütüne göre belirlenmelidir ${ }^{26}$. Çünkü taşıyıcının sorumluluğunu sınırlama hakkının kaybına yol açan kusur türlerini hükme bağlaması yönünden TTK m. 886, CMR m. 29’a koşuttur. Pervasızca

16 Simon Laimer, 'Internationaler Gütertransport auf der Strasse zwischen Einheitsprivatrecht und Kollisionsrecht' in Susan Emmenegger, Stephanie Hrubesch-Millauer, Frédéric Krauskopf and Stephan Wolf (eds), Brücken bauen Festschrift für Thomas Koller (Stämpfli 2018) 485, 494.

17 Klett, 'Haftung' (n 9) 27; Barbara Klett, 'Haftung im Strassengüterverkehr' in Barbara Klett and Andreas Furrer (eds), Schaden im Warentransport Vertragsgestaltung - Versicherung - Schadenersatz (Schulthess 2016) 132; Jesser-Huß (n 3) CMR Art. 29 N 10; Sutter (n 8) 326; Laimer (n 16) 494. Mahkeme kararları için bkz Stephan Erbe, 'Vertragliche Steuerung des Haftungsrisikos bei Transportverträgen' in Barbara Klett and Andreas Furrer (eds), Schaden im Warentransport Vertragsgestaltung - Versicherung - Schadenersatz (Schulthess 2016) 51, 55 dipnot 18.

18 Jesser-Huß (n 3) CMR Art. 29 N 10.

19 Jesser-Huß (n 3) CMR Art. 29 N 10.

20 Laimer (n 16) 495. Farklı ülkelere ilişkin değerlendirmeler için bkz Hakan Karan, Özgenur Kara ve İzel Varan, Uluslararası Eşya Taşıma Sözleşmesi Hakkında Konvansiyon CMR Şerhi (2. Bası, Yetkin 2020) 877 vd; Mustafa Erdoğan, CMR ve TTK Kapsamında Taşıyıcının Eşyanın Hasarından Doğan Sorumluluğu (1. Bası, On İki Levha 2020) 294 vd.

21 Gesetz zur Neuregelung des Fracht-, Speditions - und Lagerrechts vom 29.6.1998 (BGBI 1998 I, 1588 ff).

22 Otte (n 15) CMR Art. 29 N 5; Karl-Heinz Thume, '60 Jahre CMR Art. 29-Zankapfel damals wie heute' (2017) 4 Transportrecht 141, 141.

23 Handelsgesetzbuch (HGB) vom 10.05.1897.

24 Otte (n 15) CMR Art. 29 N 6; Jesser-Huß (n 3) CMR Art. 29 N 15; Ingo Koller, Transportrecht (9th edn, C.H.BECK 2016) CMR Art. 29 N 3a. Bunun genel eğilim olduğu yönünde bkz Kay Uwe Bahnsen, 'CMR Art. 29' in Detlev Joost and Lutz Strohn (eds), Handelsgesetzbuch Band 2 (3rd edn, C.H.BECK 2015) CMR Art. 29 N 11.

25 Bkz başlık IV, B, 2, e.

26 CMR'yi uygulayan Türk hâkiminin kasta eş değer kusur kavramı bakımından TTK m. 886’yı göz önünde bulundurması gerektiği yönünde bkz Aydın Alber Yüce, 'CMR ve TTK'da Taşıyıcının Sorumluluğu ile Kast ve Kasta Eşdeğer Kusurun Sorumluluğa Etkisi’ (2012) 3-4(Aralık-Ocak) Erciyes Üniversitesi Hukuk Fakültesi Dergisi 171, 188. Türkiye’de görülen ve CMR kapsamındaki taşıma sözleşmelerinden doğan davalar bakımından kasta eş değer kusurun, pervasızca davranış kusuru olduğu yönünde bkz Muharrem Gençtürk, 'Yeni Türk Ticaret Kanununa Göre Taşıyıcının Sınırsız Sorumluluğunu Gerektiren Ağır Kusurları ve Türk Mahkemelerinin CMR'yi Uygulaması Bakımdan Muhtemel Etkisi' (2012) XIV(4) Gazi Üniversitesi Hukuk Fakültesi Dergisi 117, 139 vd. Belirtmek gerekir ki öğretide Karan, Kara ve Varan, Türk hukukunda taşıyıcının sorumluluğu sınırlama hakkından yararlanamayacağı tek halin kasıt olduğu, kasta eş değer kusur faraziyesiyle ağır kusura başvurulamayacağı, bunun gerekçesinin de TTK m. 1429'da hükme bağlanan zararın sigorta ettirenin veya sigortalının sadece kastından doğması halinde sigortacının tazminat ödeme borcundan kurtulacağı olduğu görüşündedir. Yazarlar ayrıca 'zarar bilinerek veya zararın meydana gelme ihtimali bilinmesine rağmen, pervasızca yapılan davranış’ ifadesinin de (benzer şekilde TTK m. 886'daki ifadenin) doğrudan ve dolaylı kastı kapsadığını ifade etmektedir (Karan, Kara ve Varan (n 20) 878-881). Bu görüşün eleştirisi için bkz Gençtürk, 'Yeni' (n 26) $140-141$. 
davranış kusurunun kasta eş değer kusur olduğu hükmün gerekçesinde de ifade edilmiştir ${ }^{27}$. Bu nedenle TTK m. 886 bakımından yapılan açıklamalar, CMR m. 29'un uygulanmasında 'kasta eş değer kusur' derecesinin belirlenmesi bakımından önemlidir. TTK m. 886 ile nasıl bir değişiklik yapıldığının görülebilmesi amacıyla, 6762 sayılı Kanun döneminde taşıyıcının sınırlı sorumluluktan yararlanma hakkının kaybına yol açan ve bu anlamda kasta eş değer sayılan kusura verilen anlamın da ortaya konulması da gerekir.

\section{6762 SAYILI KANUN M. 786/3 HÜKMÜ}

6762 sayılı mülga Türk Ticaret Kanunu'nun (eTTK) ${ }^{28}$ uygulandığı dönemde, CMR'nin 29. maddesi bakımından kasta eş değer kusur, esas itibarıyla eTTK 786. madde çerçevesinde yorumlanmaktaydi ${ }^{29}$. Mülga TTK m. 786/3'te 'Zarar, taşıyıcının ă̆ır kusuru veya hilesinden doğmuş olduğu takdirde yukarki fikrada anılan halde veya bu maddenin birinci fikrası veyahut 785 inci maddedeki tazminatlar yerine tam tazminat istenebilir' hükmü bulunmaktaydı. Hükümde geçen 'hile' ifadesi ' kasıt' şeklinde anlaşılmış ${ }^{30}$, CMR m. 29'da ifadesini bulan kasta eş değer kusurun Türk hukuku bakımından esas itibarılla 'ă̆ır kusur'u ifade ettiği ve bununla kastedilenin 'ağır ihmal' olduğu sonucuna varılmıştı ${ }^{31}$.

27 Hükmün gerekçesi: “Pervasızca ve zararın muhtemelen gerçekleşebileceği bilinciyle hareket” birlikte, yani tek bir kavram olarak değerlendirilmeli ve kasta eşit bir kusur olarak yorumlanmalıdır. "Kasta eşit kusur" ölçüsü kaynak CMR m. 29 (1) hükmünde açıkça ifade edilmiştir. Bu ibarenin CMR'nin İngilizce metninde "kasıt" karşıllı̆̆ olarak "wilful misconduct" denildikten sonra "or by such default on his part as, in accordance with the law of the court or tribunal seized of the case, is considered as equivalent to wilful misconduct" denilmiştir. Bu metne göre, kasit veya davaya bakan mahkemenin veya hakemin hukukuna göre kasta eşit olarak mütalaa edilebilecek kusur söz konusudur?.

28 Türk Ticaret Kanunu (mülga), Kanun Numaras1: 6762, Kabul Tarihi: 29.06.1956, RG 09.07.1956/9353.

29 Bkz Yargitay 11 HD, E 2000/4546 K 2000/5446, 12.06.2000; Yargitay 11 HD, E 2005/12435 K 2006/12818, 5.12.2006 <https://www.kazanci.com.tr/> Erişim Tarihi 26 Temmuz 2021; Murat Uslu, CMR Hükümleri Çerçevesinde Taşıyıcının Gecikmeden Doğan Sorumluluğu (1. Bası, Seçkin 2010) 127; Ziya Akıncı, Karayolu ile Milletlerarası Eşya Taşımacılı̆̆ı ve CMR (2. Bası, Seçkin 1999) 156; Adıgüzel, 'CMR' (n 13) 364. Bu eğilimin eleştirisi için bkz Karan, Kara ve Varan (n 20) 878-879.

30 Reşat Atabek, Eşya Taşıma Hukuku (1. Bası, Sulhi Garan Matbaası 1960) 274; Yetiş Şamlı, Sorumluluk (n 12) 41; Hikmet Cem Congar, CMR ve Türk Ticaret Kanunu Hükümleri Uyarınca Karayolu Taşımacıliğında Taşıyıcının Sorumluluğu (1. Bası, Yetkin 2021) 103; eTTK 767/5'te geçen 'hile' kavramı bakımından bkz Sabih Arkan, 'Karayolu ile Eşya Taşınmasına İlişkin Uluslararası Sözleşmenin Uygulanma Koşulları ve Taşıyıcının Sorumluluğunu Düzenleyen Hükümleri (TTK İle Karşılaştırmalı Bir İnceleme)' (1979) X(2) Banka ve Ticaret Hukuku Dergisi 397, 413.

316762 sayılı Kanun döneminde kasta eş değer kusurun ağır ihmal olduğu yönünde bkz Yetiş Şamlı, Sorumluluk (n 12) 4142; Uslu (n 29) 127; Ecehan Yeşilova, Taşıyıcının CMR Hükümlerine Göre Yardımcı Şahıslarının ve Müteakip Taşıyıcıların Eylemlerinden Doğan Sorumluluğu (1. Bası, Yetkin 2004) 98; Sabih Arkan, 'CMR Hükümlerine Göre Yardımcıların Fiillerinden Doğan Sorumluluk' in Mürsel Başgül ve Haluk Konuralp (edr), Prof. Dr. Yaşar Karayalçın’a 65. Yaş Armağanı (Türkiye İş Bankası Kültür Yayınları 1988) 319, 333; bu konuda yapılan tespit için bkz Burak Adıgüzel, 'Yeni Türk Ticaret Kanunu’nda Eşya Taşıma Hukuku Alanında Getirilen Yenilikler' (2012) 18(2) Marmara Üniversitesi Hukuk Fakültesi Hukuk Araştırmaları Dergisi 769, 786; Adıgüzel, 'CMR' (n 13) 365, 373; ancak Yazar kasta eş değer kusurun ağır ihmalden daha nitelikli bir kusur derecesi oluşturduğu, ancak kast denilen kusur derecesinin de altında bir nitelik arz ettiği düşüncesindedir, bkz Adıgüzel, 'CMR (n 13) 372. Özdemir, kasta yakın derecede ağır kusurun, CMR m. 29'da aranan kusur şartını gerçekleştirdiği görüşündedir, bkz Turkay Özdemir, Uluslararası Eşya Taşıma Hukuku (Zıya ve/veya Hasar Sorumluluğu) (1. Bası, Vedat 2006) 176. Bu noktada belirtmek gerekir ki, öğretide Karan, Kara ve Varan, kasta eş değer kusurun belirlenmesinde, sigortacının hangi kusur türünde tazminat ödemekten kurtulacağının öngörüldüğü eTTK 1278'in dikkate alınması gerektiği, bu sebeple eTTK m. 786'dan hareketle kasta eş değer kusurun ağır ihmal olarak değerlendirilmeyeceği görüşündedir, bkz Karan, Kara ve Varan (n 20) 878-879. 
Hal böyle olmakla birlikte, 6102 sayılı TTK'de kasıt veya pervasızca davranış kusuru şeklinde iki kademeli nitelikli kusur hali öngörülerek 'hile’ ve 'ağır kusur'biçimindeki kusur derecelendirmesinden vazgeçilmiştir. Anılan kusur derecesi düzenlenirken, 6102 sayılı Kanun’un 855/5, 887, 930/2, 1187 ve 1267 madde hükümleri arasında terim birliği ve uygulama açısından yeknesaklık sağlanması amaçlanmıştır ${ }^{32}$.

\section{NITELIKLI KUSUR HALLERi}

Hukuk düzeninin fertlerden beklediği ortalama hareket tarzından sapan davranışlar kusurlu olarak nitelendirilir ${ }^{33}$. Türk hukukunda kusur, geleneksel olarak ' $k a s ı t$ 've 'ihmal' şeklinde ikili bir ayrıma tâbi tutulur. Ayrıca kasıt bakımından 'doğrudan kasıt-dolayl kasıt', ihmal bakımından 'ă̆ır ihmal-hafif ihmal' ve 'bilinçli ihmal-bilinçsiz ihmal' şeklinde bir alt ayrıma daha gidilir. Sorumluluğu sınırlama hakkının kaybı, 6762 sayılı Kanun'un uygulandığı dönemde m. 786/3 hükmü dolayısıyla 'kasıt' ve 'ağır ihmal' olarak kabul edilirken; bu durum TTK m. 886 'da 'kasıt' ve 'pervasızca ve böyle bir zararın meydana gelmesi ihtimalinin bilinciyle işlenmiş bir davranış’ kusuruna dönüşmüştür. Çalışmada her iki kusur türünü kapsayacak şekilde 'nitelikli kusur' ifadesi kullanılmıştır. Madde metninde geçen kasıt kavramı bakımından bir yorum sorunu genellikle yaşanmazken, ikinci kusur derecesinin Türk hukukunda yerleşik kusur ayrımlarından birine girip girmediği, soruya olumlu cevap verilmesi halinde hangi kusur derecesine tekabül ettiği konusunda görüş ayrılıkları bulunmaktadır.

\section{A. KASIT}

Türk hukukunda, hem haksız fiil hem sözleşme sorumluluğunda, borçlunun sorumlu tutulabilmesi için kusurun derecesi prensip olarak önemli değildir ${ }^{34}$. Bununla birlikte hâkim, Türk Borçlar Kanunu $(\mathrm{TBK})^{35} \mathrm{~m}$. 51/1 hükmü gereğince tazminatı belirlerken şüphesiz kusurun ağırlı̆̆ını göz önünde bulundurur. Ayrıca bazı hükümlerin uygulanması bakımından, TTK m. 886'da olduğu gibi, kusurun dereceleri arasında ayrım yapıldığı da görülmektedir ${ }^{36}$. Hükmün gerekçesinde maddenin kaynakları olarak gösterilen CMR m. 29 ile AlmTK $\$ 435$, TTK m. 886'da olduğu gibi, iki nitelikli kusur hali öngörmektedir. Bunlardan ilki kasit olup, anılan kavramın Alman hukukunda hem doğrudan hem dolaylı kastı kapsadığı kabul edilmektedir ${ }^{37}$. CMR'nin İngilizce metninde 'wilful misconduct';

32 TTK m. 930, 1187 ve 1297 gerekçesi.

33 Haluk Tandoğan, Türk Mes'uliyet Hukuku (Akit Dışı ve Akdî Mes'uliyet) (2. Bası, Vedat 2010) 46; Fikret Eren, Borçlar Hukuku Genel Hükümler (21. Bas1, Yetkin 2017) 592.

34 Feyzi Necmeddin Feyzioğlu, Borçlar Hukuku Genel Hükümler Cilt 1 (2. Bası, Fakülteler Matbaası 1976) 478.

35 Türk Borçlar Kanunu, Kanun Numarası: 6098, Kabul Tarihi: 11.01.2011, RG 04.02.2011/27836.

36 Örneğin TBK m. 49/2, 115, 225, 294.

37 Otte (n 15) CMR Art. 29 N 3; Karl-Heinz Thume, 'HGB $\$ 435$ ' in Karsten Schmidt (ed), Münchener Kommentar zum Handelsgesetzbuch (4th edn, C.H.BECK 2020) HGB $\$ 435$ N 9; Hanno Merkt, 'HGB $\$ 435$ ’ in Baumbach Adolf and Klaus J. Hopt (eds), Handelsgesetzbuch (39th edn, C.H.BECK 2020) HGB $₫ 435$ N 2; Marian Paschke, 'HGB $₫ 435$ ’ in Hartmut Oetker (ed), Handelsgesetzbuch (6th edn, C.H.BECK 2019) HGB $\$ 435$ N 3; Wolfgang Schaffert, 'HGB $\$ 435$ ' in Detlev Joost and Lutz Strohn (eds), Handelsgesetzbuch Band 2 (3rd edn, C.H.BECK 2015) HGB $\$ 435$ N 4; Günter Kirchhof, 'HGB $\$ 435$ ' in Martin Häublein and Roland Hoffmann-Theinert (eds), Beck'sche Online-Kommentare HGB (27. Edition, 15.1.2020) HGB $\$ 435 \mathrm{~N} 4$. Bu konuda görüş birliği olduğu yönünde bkz Karl-Heinz Thume, 'Durchbrechung der 
Fransızca metninde 'dol' ifadeleri kullanılmıştır ${ }^{38}$ ve bu ifadeler hem dolaylı hem doğrudan kastı kapsayacak şekilde yorumlanmaya müsaittir ${ }^{39}$.

Türkhukukundakasıtkavramı, hem doğrudan hem dolaylıkastıkapsayacakşekildekullanılmaktadır ${ }^{40}$. Şu halde TTK m. 886/1'de ifadesini bulan 'kasıt' kavramı bu minvalde yorumlanmalıdır. Doğrudan kasıt (dolus directus), bir kimsenin hukuka aykırı fiili ${ }^{41}$, hukuka aykırı sonucu ${ }^{42}$, zararlı sonucu ${ }^{43}$ 'bilme'si ve 'isteme'si olarak tanımlanmaktadır Kastın failin bilerek ve isteyerek bir başkasına zarar vermesi şeklinde tanımlandığı da görülmektedir ${ }^{44}$. Kastta isteme unsuru doğrudan değil, dolaylı şekilde tezahür edebilir; bu halde dolaylı kasıt söz konusu olur. Dolaylı/ihtimali/muhtemel/olası kastta (dolus eventualis/bedingter Vorsatz) kişi hukuka aykırı sonucu ${ }^{45}$, zararlı sonucu ${ }^{46}$ bilmektedir; bunu istememekte, fakat sonucu göze almakta, kabullenmektedir ${ }^{47}$. Failin fiil ile illiyet bağı içerisinde ortaya çıkan ve tazmini gereken zararların biçimini ve kapsamını öngörmüş ve istemiş olması ise gerekli değildir ${ }^{48}$.

TTK m. 886'da geçen kasıt kavramı bakımından, taşıyıcının zarar verme amacıyla (saikiyle) hareket etmesi (Absicht) gerekli değildir. Adı geçen hükümde yer alan 'zarara, kasten... sebebiyet verdiğ ispat edilen taşıyıcı' ifadesi kastın, hukuka aykırı davranışa yönelik olduğunu göstermektedir. Hukuk dilinde burada olduğu gibi 'hareket tarzının niteliğini'n 'hareket tarzı' yerine kullanılması vakidir ${ }^{49}$. Aslında ifade edilmek istenen 'zarara kasitlı bir hareket tarzıyla' sebebiyet vermektir. O

Haftungsbeschränkung nach $₫ 435$ HGB im internationalen Vergleich’ (2002) 1 Transportrecht 1, 2.

38 CMR m. 51.

39 Otte (n 15) CMR Art. 29 N 3; Jesser-Huß (n 3) CMR Art. 29 N 5. Ayrıca bkz Arslan Kaya, 'Taşıyııının Kara Yolu ile Eşya Taşımasına İlişkin Uluslararası Sözleşme’de (CMR) Öngörülen Sorumluluğunun Esasları (II)’ (1998) 56(1-4) İstanbul Üniversitesi Hukuk Fakültesi Mecmuası 239, 267; Aksoy Yavaş, Kara Yolunda Konteyner ile Yapılan Yük Tașımasında Kayıp veya Hasardan Doğan Sorumluluk (1. Bası, On İki Levha 2016) 200.

40 Eren (n 33) 597; Hüseyin Hatemi, Necip Kocayusufpaşaoğlu, Rona Serozan ve Abdulkadir Arpacı, Borçlar Hukuku Genel Bölüm Cilt 2 (2. Bası, Filiz 1998) \$ 7 N 13; M. Kemal Oğuzman ve M. Turgut Öz, Borçlar Hukuku Genel Hükümler Cilt II (13. Bası, Vedat 2017) N 158; Selahattin Sulhi Tekinay, Sermet Akman, Haluk Burcuoğlu ve Atilla Altop, Tekinay Borçlar Hukuku Genel Hükümler (7. Bas1, Filiz 1993) 493.

41 Tekinay, Akman, Burcuoğlu ve Altop (n 40) 493; Haluk N. Nomer, Borçlar Hukuku Genel Hükümler (14. Bası, Beta 2015) 153.

42 Hatemi, Kocayusufpaşaoğlu, Serozan ve Arpacı (n 40) § 7 N 13; Tandoğan (n 33) 46; Zahit İmre, Doktrinde ve Türk Hukukunda Kusursuz Mesuliyet Halleri (1. Bası, İsmail Akgün Matbaası 1949) 26. Zararlı sonucu bilme ve isteme şeklinde yapılan bir tanımlama için bkz Ahmet M. Kılıçoğlu, Borçlar Hukuku Genel Hükümler (21. Bası, Turhan 2017) 406; Oğuzman ve Öz (n 40) N 158, ancak karş N 154.

43 Damla Gürpınar, Sözleşme Dışı Yanlış Tavsiyede Bulunma, Öğüt veya Bilgi Vermeden Doğan Hukuki Sorumluluk (1. Bası, Güncel 2006) 123. Failde hem zararlı sonuç hem de hukuka aykırılık bilincinin olması gerektiği yönünde bkz Eren (n 33) 598.

44 Pınar Çağlayan Aksoy, Hukuka Aykırıllk ve Ahlaka Aykırılık Unsurları Çerçevesinde Salt Malvarlğı Zararlarının Tazmini (1. Bas1, On İki Levha 2016) 371.

45 Hatemi, Kocayusufpaşaoğlu, Serozan ve Arpacı (n 40) $\$ 7$ N 13; Kadir Berk Kapancı, Ahlaka Aykırı Bir Fiille Kasten Verilen Zararin Tazmini (1. Bası, Vedat 2016) 27.

46 Çağlayan Aksoy (n 44) 375.

47 Dolaylı kasıt hakkında bkz ve karş Oğuzman ve Öz (n 40) N 158; Tandoğan (n 33) 47; Hatemi, Kocayusufpaşaoğlu, Serozan ve Arpacı (n 40) \$ 7 N 13; Eren (n 33) 596; Tekinay, Akman, Burcuoğlu ve Altop (n 40) 493.

48 Tandoğan (n 33) 47; Oğuzman ve Öz (n 40) N 158.

49 Tandoğan (n 33) 45. 
halde taşıyıcının kanundan doğan veya sözleşmede kararlaştırılan ve uyulması halinde zararın doğmasını engelleyecek yükümlülüklerini kasten ihlal etmesi yeterlidir. Eklemek gerekir ki failin zarar verme amacıyla hareket etmesi, kastın en ağır halidir ${ }^{50}$. Dolayısıyla bu fiiller de kasten işlenen fiiller içerisinde mütalaa edilir ${ }^{51}$.

\section{B. PERVASIZCA DAVRANIŞ KUSURU}

\section{Genel Bakış}

Sorumluluk sınırlamalarından yararlanma hakkını ortadan kaldıran ikinci nitelikli kusur hali, Kanun metninde 'pervasızca bir davranışla ve böyle bir zararın meydana gelmesi ihtimalinin bilinciyle işlenmiş bir fiilin veya ihmalin' mevcut olması şeklinde formüle edilmiştir. Pervasızca ve zararın meydana gelmesi ihtimalinin bilinci ile davranma tek bir kavram olarak değerlendirilmelidir ${ }^{52}$. Dolayısıyla burada 'i) pervasızca davranış niteliğinde bir yükümlülük ihlali ve ii) zararın doğması ihtimaline ilişkin bir bilinç’ olmalı ve bu iki unsurun mevcudiyeti ayrı ayrı aranmalıdır.

Pervasızca davranış kusuru, Türk hukukuna tamamen yabancı değildir. 12 Ekim 1929 tarihinde Varşova'da imzalanan 'Uluslararası Hava Taşımalarına İlişkin Bazı Kuralların Birleştirilmesi Hakkındaki Sözleşme’nin 28 Eylül 1955 tarihli Lahey Protokolü ile değiştirilen 25. maddesinde taşıyıcının işçilerinin veya temsilcilerinin 'zararın doğması ihtimali olduğunu bilerek dikkatsizce yaptıkları bir hareket veya ihmal sonucu meydana geldiğg ${ }^{53}$ hallerde sınırlı sorumluluktan yararlanma hakkının ortadan kalkacağı öngörülmüştür. Benzer şekilde Türk Sivil Havacıllk Kanunu (TSHK) ${ }^{54}$ m. 126'da 'zararın doğması ihtimali olduğunu bilerek dikkatsizce yaptıkları bir hareket veya ihmal sonucunda meydana gelmesi' ifadelerine yer verilmiştir ${ }^{55}$. Dolayısıyla TTK m. 886 'da öngörülen ikinci kusur derecesi, Varşova Sözleşmesi’nin değişik 25. maddesi ve bu ifadeyi tercih eden muhtelif metinler ile uluslararası sözleşmelerde yer alan formül ile benzerdir ${ }^{56}$.

50 Çağlayan Aksoy (n 44) 371; Gürpınar (n 43) 123.

51 TTK m. 886'nın hükûmet tarafından sunulan halinde 'taşıyıcının böyle bir zarara sebep olmak kastı' ifadesi yer almaktaydı. Ancak Adalet Komisyonu tarafından metinde değişiklik yapılmış ve kasıt teriminin Türk hukukunda bu anlamı zaten içerdiği ifade edilmiştir. <https://www.tbmm.gov.tr/tutanaklar/TUTANAK/TBMM/d23/c032/tbmm23032022ss0096. pdf $>$ 523, Erişim Tarihi 28 Temmuz 2021.

52 Madde gerekçesi.

53 Resmi çeviri için bkz RG 03.12.1977/16128. Bu şekilde yapılan resmi çevirinin eleştirisi ve çeviri önerisi için bkz Tahir Çağa, ‘Enternasyonal Deniz Hususi Hukukunda Yeni Bazı Gelişmeler', (1977) 9(2) Banka ve Ticaret Hukuku Dergisi 289, 300-301.

54 Türk Sivil Havacılık Kanunu, Kanun Numarası: 2920, Kabul Tarihi: 14.10.1983, RG 19.10.1983/18196.

55 Nurdan Orbay Ortaç, 'Havayolu ile Taşımalarda Bagajın Zıyaı veya Hasara Uğraması Nedeniyle Doğan Akdi Sorumluluk' (2014) 114 Türkiye Barolar Birliği Dergisi 143, 164.

56 Varşova Sözleşmesi’nin değişik 25. maddesindeki ifadenin kullanıldığı sözleşmeler hakkında bkz Duygu Damar, 'Milletlerarası Taşıma Hukukunda "Wilful Misconduct" - Kavramın Tarihçesi ve Tercümesi' (2004) 24(1-2) Milletlerarası Hukuk ve Milletlerarası Özel Hukuk Bülteni 379, 386 vd. 


\section{Kusurun Niteliğine İlişkin Görüşler}

Pervasızca davranış kusuruna nasıl bir anlam verilmesi gerektiği konusunda yapılan açıklamalar ile Varşova Sözleşmesi’nin 25. maddesine ve benzer kusur türünü düzenleyen diğer hükümlere ilişkin yorumlar dikkate alındığında, bu kusur derecesinin ne olduğu konusunda fikir birliğinin bulunmadığı görülmektedir. Öğretide, farklı veya benzer gerekçeler ile anılan kusur türünün 'dolaylı kasıt', 'ağır ihmal', 'bilinçli ihmal/bilinçli ağır ihmal' olduğu düşüncesinde olan müellifler bulunduğu gibi, bu kusurun 'Kara Avrupası hukuk sistemlerinde bilinen kusur türlerinden hiçbirine uymadığı, bu sebeple kanunda verilen unsurların dikkate alınması suretiyle her bir olay bakımından ayrı ayrı değerlendirme yapılması gerektiği’ fikrini savunanlar da vardır:

\section{a. Dolaylı Kasıt Olduğu Görüşü}

Yukarıda belirtilen çerçevede bazı yazarlar tarafından pervasızca davranış kusurunun 'dolaylı kasıt' olduğu ileri sürülmüştür ${ }^{57}$. CMR m. 29 bakımından konuyu inceleyen Karan, Kara ve Varan, CMR m. 29'da geçen kasıt kavramı için orijinal Fransızca metinde ' dol', İngilizce metinde ise “ wilful misconduct' ifadelerinin kullanıldığı, bu kavramların ortak özelliğinin sigortacıyı sigortalısına karşı tazminat ödeme yükümlülüğünden kurtaran kasıtlı davranış şeklini ortaya koyduğu, bu kavramlara ulusal hukuklarda aynı anlamın verilmeyeceği düşünülerek kasta (dol/wilful misconduct) eş değer sayılan ihlallere, yani sigortacının sigorta tazminatı ödemekten kurtulabileceği kusur türüne aynı hükmü uygulama yetkisi verildiği, TTK m. 1429'da zararın sigorta ettirenin veya sigortalının sadece kastından doğması halinde sigortacının tazminat ödemekle yükümlü olmayacağının düzenlendiği, bu nedenle Türk hukuku bakımından taşıyışının sorumluluğunu sınırlama hakkından yararlanamayacağı tek halin kasıt olduğu, kasta eş değer kusur faraziyesiyle ağır ihmale başvurulamayacağı, TTK m. 886'da yer verilen 'zararın bilinmesi' ile doğrudan kastın, "zararın meydana gelme ihtimali bilinmesine rağmen, pervasızca yapılan davranış’ ile dolaylı kastın ifade edildiği gerekçeleriyle bu sonuca varmıştır ${ }^{58}$.

Kahraman, kişinin zarar tehlikesini tahmin etmesine rağmen, davranışlarını bu bilinçle sürdürmesinin zararın gerçekleşmesini göze aldığı ve kabullendiği anlamına geleceği gerekçesiyle pervasızca davranış kusurunun olası kast olduğu görüşündedir ${ }^{59}$. Damar, pervasızca davranış kusuru ile dolaylı kastın unsurları bakımından yaptığı ayrıntılı karşılaştırma sonucunda, pervasızca davranış kusurunun dolaylı kasta denk geldiği sonucuna varmıştır ${ }^{60}$.

57 Karan, Kara ve Varan (n 20) 880; Zafer Kahraman, 'Medeni Hukuk Bakımından Pervasızca Hareket' iç Saibe Oktay Özdemir, Azra Arkan Serim ve Atilla Altop (edr), Prof. Dr. Sermet Akman'a Armağan (Filiz Kitabevi 2020) 425; Duygu Damar, Wilful Misconduct in International Transport Law (1st edn, Springer 2011) 269-290; Damar, 'Costa Concordia' (n 2) 292. Ülgen, sözü geçen kusur türünün dolaylı kast olduğu görüşünde olmasına rağmen, menfaatler durumu açısından daha uygun olduğundan taşıyıcının ağır ihmali halinde de sınırsız sorumluluğun şartlarının oluşması gerektiği düşüncesindedir, bkz Hüseyin Ülgen, Hava Taşıma Sözleşmesi (1. Bası, Banka ve Ticaret Hukuku Enstitüsü 1987) 203.

Karan, Kara ve Varan (n 20) 876 vd.

59 Kahraman (n 57) $421 \mathrm{vd.}$

60 Damar, Wilful Misconduct in International Transport (n 57) 269-290; Damar, 'Costa Concordia' (n 2) 292. 


\section{b. Ağır İhmal Olduğu Görüşü}

Öğretide, bir diğer görüş olarak pervasızca davranış kusurunun 'ağır ihmal' olarak kabul gördügüne işaret edilmektedir ${ }^{61}$.

\section{c. Bilinçli Ağır İhmal/Bilinçli İhmal Olduğu Görüşü}

Bir başka görüş, öngörülen kusur ölçütünün 'bilinçli ağır ihmal/bilinçli ihmal' olduğu şeklindedir. Anılan görüşte olan Yavaş, pervasızca davranış kusurunda, pervasızca davranışın taşıyıcının yükü korumak için göstermesi gereken en basit dikkat ve özeni göstermemesi olduğu, bu yönden anılan unsurun ağır ihmale denk geldiği, zarar ihtimaline ilişkin bilinç unsuru ile değerlendirildiğinde failin hukuka aykırı neticeyi öngördüğ̈̈; ancak bu sonucu istemediği, netice olarak pervasızca davranış kusurunun bilinçli ihmal olduğu, bilinçli ihmalin de ağır ihmalin en ağır hali olduğu düşüncesindedir ${ }^{62}$.

Sözer, belirtilen kusur türünün kasti bir davranışta olduğu kadar ağır bir kusur teşkil etmediği, ancak hafif ihmalin de yeterli olmayacağı, bilakis ağır ihmal mahiyeti taşıdığı, davranışın zarara yol açacağının da bilinmiş olması arandığından bilinçli ihmalin söz konusu olduğu görüşündedir ${ }^{63}$. Yazar, netice olarak kasıt veya ağır ihmal halinde sorumluluğun sınırsız olacağını ifade etmekle birlikte, açıklamalarında failde aranan zarar bilinci sebebiyle davranışın bilinçli ihmal teşkil ettiği bilgisine de yer vermektedir.

\section{d. Kara Avrupası Hukuk Sistemlerinde Bilinen Kusur Türlerinden Hiçbirine Uymadığı Görüşü}

İleri sürülen son görüş, pervasızca davranış kusurunun Kara Avrupası hukuk sistemlerinde bilinen kusur türlerinden hiçbirine uymadığı yönündedir ${ }^{64}$. Anılan görüşte olan yazarlar pervasızca davranış

61 Tuba Birinci Uzun, Uluslararası Hava Taşımalarında Taşıyıcının Sorumluluğu (3. Bası, Seçkin 2020) 196 vd. Ağır ihmalin yeterli olmayacağı yönünde bkz Muharrem Gençtürk ve İlhan Yiğit, 'CMR Kapsamındaki Taşımalarda Taşıyıcının Sınırlı Sorumluluktan Yararlanamayacağı Haller’ (2013) 3 Gaziosmanpaşa Bilimsel Araştırma Dergisi 34, 39; Duygu Damar, 'Neues türkisches Handels - und Transportrecht' (2013) 5 Transportrecht 171, 183.

62 Yavaş, 'Kusur Türleri' (n 12) 219 vd; Yavaş, Konteyner (n 39) 225; bkz ve karş Gözde Cömert Varol, Kara Yolunda Yapılan Eşya Taşımalarında Taşıyııının 6102 Sayılı Türk Ticaret Kanunu ve CMR Konvansiyonu Kapsamında Kayıp veya Hasardan Kaynaklanan Sorumluluğu (1. Bası, On İki Levha 2020) 188 vd.

63 Bülent Sözer, Deniz Ticareti Hukuku Cilt 1 (5. Bası, Vedat 2019) 291 vd; Bülent Sözer, Türk Hukuku’nda ve Uluslararası Hukuk'ta Havayolu ile Yük Taşıma Sözleşmesi (2. Bası, Vedat 2009) 235, 240 vd; Bülent Sözer, 'Türk Sivil Havacılık Kanunu’nun Hükümlerine Göre Taşıyanın ve İşletenin Sorumluluğu’ (1984) 12(4) Banka ve Ticaret Hukuku Dergisi 3, 57-58. Ağır kusura ve bir ölçüde de şuursuz (ihtimali) kasta veya şuurlu taksire tekabül ettiği yönünde bkz Can (n 2) 104.

64 Çağa ( n 53) 301 vd; Emine Yazıcıŏ̆lu, Hamburg Kurallarina Göre Taşıyanın Sorumluluğu (1. Bası, Beta 2000) 170-175; Atalay Özdemir, Hava Taşıyıcısının Sorumluluğu (1. Bası, Sanem Matbaacılık 1992) 118-119; Yetiş Şaml, Sorumluluk (n 12) 94 vd; Kübra Yetiş Şamlı, 6102 Sayılı Türk Ticaret Kanunu’na Göre Taşıyanın Zıya Hasar ve Geç Teslimden Sorumluluğu (2. Bası, On İki Levha 2013) 169 vd; Ergon Çetingil, 'Alman Deniz Ticareti Hukukunun 1986 Yılı Reformunda Taşıyanın Sorumluluğu ile İlgili Olarak Yapılan Değişiklikler', (1992) 16(4) Banka ve Ticaret Hukuku Dergisi 21, 34; Adıgüzel, Taşıma (n 2) 240 vd; ayrıca bkz Adıgüzel, 'Yenilikler' (n 31) 786; Burak Adıgüzel, Karayoluyla Yapılan Taşımalarda Taşıyıcının Zıya ve Hasardan Doğan Sorumluluğu (2. Baskı, Adalet 2012) 232 vd.; pervasızca davranış kusurunu Türk hukukundaki kusur dereceleri ile örtüștürmenin sağlıklı olmayacağı yönünde bkz Süzel (n 2) 558. 
kusurunun kendi unsurları içerisinde değerlendirilmesi ve somut olayda bu unsurların gerçekleşip gerçekleşmediğinin sorgulanması gerektiği fikrindedir. Bununla birlikte bazılarının pervasızca davranış kusurunun hukukumuzda bilinen kusur derecelerinden hangilerinin arasına tekabül ettiği veya hangisine yakın olduğu şeklinde değerlendirmeler yaptığı da görülmektedir:

Yazıcıoğlu, pervasızca davranış kusuru bakımından failin muhtemelen zarar meydana geleceğinin bilincinde olması gerektiği, oysa zarar bilincinin olmadığı hallerde de ağır ihmalin söz konusu olabileceği, dolayısıyla anılan kusur türünün ağır ihmal olmadığı, zarar bilincinden maksadın zararın meydana gelme olasılığının gelmeme olasılığından yüksek olduğunun bilinmesi anlamına geldiği, bilinçli ihmalde failin zarar olasılığını görmesine rağmen bu olasıllğın düşük olduğuna ilişkin bir güveni olduğu, bu yönden bu kusur türünün bilinçli ihmal de olmadığı, dolaylı kastta zarar olasılığının yüksek olması şartının aranmadığı, bu sebeple anılan kusur türünün dolaylı kasıt olarak da nitelendirilemeyeceği ${ }^{65}$, belirtilen sebeplerle pervasızca davranış kusurunun dolaylı kasta yakın, fakat ağır ihmal ile dolaylı kasıt arasında yer alan bir kusur türü olduğu düşüncesindedir ${ }^{66}$. Yetiş Şamlı, bu açıklamalara katılmakla birlikte sınırsız sorumluluğa yol açan bu kusur türünün bağımsız bir kusur türü olarak görülmesi ve unsurlarının oluşup oluşmadığının her bir olay bakımından ayrı ayrı değerlendirilmesi gerektiğini ifade etmektedir ${ }^{67}$.

Özdemir, burada failin zarar ihtimalini bilmesine rağmen bunu istememesi sebebiyle dolaylı kastın bulunmadığı, failde aranan bilincin yüksek zarar ihtimaline ilişkin olması zorunluluğu sebebiyle bilinçli ağır ihmalin de söz konusu olmadığı, dolaylı kasta yakın ve bilinçli ağır ihmal ile dolaylı kasıt arasında yer alan bir kusur türü olduğu fikrindedir ${ }^{68}$. Adıgüzel, ağır ihmalden daha nitelikli, ancak kasıt derecesinin altında kalan bir kusur türü olduğu, değerlendirmede ele alınacak ölçütün pervasızca davranış kavramının objektif ve sübjektif yönleri olacağı düşüncesindedir ${ }^{69}$.

Gençtürk, bahsi geçen kusur türünün hukukumuzda bilinen ve yerleşik kusur kavramlarından farklı olduğu, ancak Türk hukukuna tamamen yabancı da olmadığı, çünkü TSHK m. 126'da bu kusur türünün tanımladığı, bahsi geçen kusur derecesinde i) pervasızca bir davranış, ii) zararın meydana gelmesi hususunda galip (yüksek) ihtimal ve iii) bu ihtimal konusunda taşıyıcının şuura sahip olması şeklinde üç unsurun bulunduğu, söz konusu kusurun mevcudiyeti tespit edilirken bu unsurların varlığı veya yokluğuna göre karar verilmesi gerektiği, iç hukukta yerleşmiş kavramlardan bağımsız olarak değerlendirilme yapılmasının uygun olacağı, anılan kusur türünde failin zararlı sonucu tasvip etmesi şart olmadığından olası kastın, zarar bilincinin aranması sebebiyle ağır ihmalin, zarar ihtimalinin galip ihtimal olması gerektiğinden bilinçli ihmalin söz konusu olmadığı, bununla

65 Çağa (n 53) 301 vd.

66 Yazıcıoğlu (n 64) 170-175.

67 Yetiş Şamll, Sorumluluk (n 12) $94 \mathrm{vd}$.

68 Özdemir (n 64) 118-119.

69 Adıgüzel, Taşıma (n 2) 240 vd; ayrıca bkz Adıgüzel, 'Yenilikler' (n 31) 786; Adıgüzel, Karayoluyla (n 64) 232 vd. CMR m. 29'da yer alan kasta eş değer kusurun benzer şekilde değerlendirileceği, CMR m. 29'un uygulanması bakımından TTK m. 886'nın göz önünde bulundurulacağı şeklinde bkz Yüce, (n 26) 185. 
birlikte pervasızca davranış kusurunun sadece bazı somut olaylarda bilinçli ihmal ile uyuşabileceği görüşündedir ${ }^{70}$.

Süzel, pervasızca davranış kusurunun Türk hukukundaki kusur dereceleri ile örtüştürmenin sağl1kl olmayacağı, her bir olay bakımından anılan kusur türünün somut olayda mevcut olup olmadığının kanunda aranılan unsurlar bakımından değerlendirilmesi gerektiği, kusurun pervasızlık unsuru ile bilinçli bir şekilde ve makul olmayan bir riskin alınması biçiminde gerçekleşen hukuka aykırı bir davranışın kastedildiği, zarar bilinci bakımından ise, failin hukuka aykırı sonucu istemesinin şart olmadığı, sonucun gerçekleşebileceği öngörülmesine rağmen, gerçekleşip gerçekleşmediğinde umursamazlığın söz konusu olduğu, zararın doğma olasılığı bakımından zararın kesin olarak meydana gelecek olmasının zaruri olmadığı, zarar verme ihtimalinin de tek başına yeterli olmayacağı, çünkü zarar doğması olasılığının 'muhtemel' olması, daha açı anlatımla zararın doğma olasılığının doğmama olasılığından yüksek olması gerektiği görüşündedir ${ }^{71}$.

\section{e. Alman Hukukundaki Görüşler}

Pervasızca davranış kusurunun yorumlanmasında, gerekçede hükmün mehazı olarak zikredilen AlmTK $₫ 435$ bakımından yapılan yorumlara da bakmak gerekir. Öncelikle belirtmek gerekir ki bu yeni kusurun nasıl yorumlanacağı konusunda Alman hukukunda da farklı fikirler ileri sürülmüştür. Genel eğilim, pervasızca davranış kusurunun Kanun’a girmesiyle, sınırsız sorumluluğun şartlarının ağır ihmale nazaran ağırlaştı̆̆ı yönündedir ${ }^{72}$. Bir görüş, getirilen yeni kusur ölçütünün Alman Medeni Kanunu'na ${ }^{73}$ yabancı olduğu ve 'ağı ihmal ile dolayl kastt' arasında bir kusur derecesine denk geldiğ $\mathrm{i}^{74}$, bir diğer görüş 'bilinçli ağır ihmal ile dolaylı kasıt' arasında olduğu şeklindedir ${ }^{75}$. Bazı yazarlar ise ağır ihmal niteliğindeki bir davranışın ve failde zarar ihtimaline ilişkin bilincin arandığ 1 bir kusur türü olduğu düşüncesini savunmuştur ${ }^{76}$.

\section{Değerlendirme ve Kanaat}

Aşağıda bu yeni kusur derecesinin nasıl yorumlanması gerektiği konusunda şahsi kanaatimize yer verilmiștir. Bu noktada pervasızca davranış kusurunun 'pervasızca davranış' ve 'zararın muhtemelen meydana geleceğine ilişkin bilinç’ şeklindeki iki unsuru bakımından ayrı ayrı açıklama yapılması ve

70 Gençtürk, 'Yeni' (n 26) 123, 134 vd.

71 Açıklamalar ve TTK m. 1187 bakımından pervasızca davranış kusurunun yabancı ve Türk yargı kararları çerçevesinde değerlendirilmesi için bkz Süzel (n 2) 558-582.

72 Kirchhof (n 37) HGB $₫ 435$ N 5; Rolf Herber, 'Die Neuregelung des deutschen Transportrechts' (1998) Neue Juristische Wochenschrift 3297, 3304; Fritz Fremuth, 'Haftungsbegrenzungen und deren Durchbrechung im allgemeinen deutschen Frachtrecht und nach der CMR' (2004) 3 Transportrecht 99, 99; Thume, 'Kommentar' (n 37) HGB § 435 N 11; Thume, '60 Jahre' (n 22) 142; Thume, 'Durcbrechung' (n 37) 2 ff.

73 Bürgerliches Gesetzbuch (BGB) vom 18.08.1896.

74 Kirchhof (n 37) HGB $\$ 435$ N 5: '...zwischen grober Fahrlässigkeit und bedingtem Vorsatz'.

75 Merkt (n 37) HGB $₫ 435$ N 2: ‘... zwischen bewusster grober Fahrlässigkeit und bedingtem Vorsatz’.

76 Thume, 'Kommentar' (n 37) HGB $₫ 435$ N 11. 
öğretide yer alan görüşlerin de yapılan açıklamalar ışı̆̆ında değerlendirilmesi ve sonuca varılması şeklinde bir yol tercih edilmiştir.

\section{a. Pervasızca Davranış Kusurunun Unsurları}

\section{aa. Pervasızca Davranış}

Alman hukukunda pervasızca davranış, taşıyıcı veya yardımcılarının sözleşmenin diğer tarafının teslim ettiği eşya üzerindeki güvenlik menfaatlerini bariz bir şekilde göz ardı ettiği ve temel koruma önlemlerini dahi dikkate almadiğı çok ağır yükümlülük ihlali şeklinde ifade edilmektedir ${ }^{77}$. Ağır ihmal ise, her makul insanın aynı durum ve şartlar altında aşikâr sayacağı en basit dikkat ve özenin gösterilmemiş olması, alınması gereken en basit önlemin dahi alınmaması biçiminde tanımlanmaktadır ${ }^{78}$. Bu tanım ile yukarıda yapılan pervasızca davranış tanımı dikkate alındığında, iki kavramın ağırlık yönünden benzer olduğu görülmektedir. Bu nedenle kusurun 'pervasızca davranış’ unsurunun geleneksel kusur ayrımı içerisinde ağır ihmalle işlenen fiillere denk geldiği sonucuna varılmalıdır. Nitekim öğretide de, yukarıda ifade edildiği üzere, bu yönde görüş beyan eden müellifler bulunmaktadır ${ }^{79}$.

Pervasızca ve zarar bilinciyle yapılan her davranışın ağır ihmal teşkil ettiğine şüphe yoktur. Ancak her ağır ihmalin pervasızca davranış kusuru bakımından yeterli olduğunun peşinen kabul edilmesi mümkün değildir ${ }^{80}$. Çünkü Kanun, kastın olmadığı hallerde sınırsız sorumluluk için, 'pervasızca davranış' ve buna ilave olarak failde 'zarar bilinci'nin bulunmasını şart koşmaktadır. Sınırsız sorumluluğun şartlarının, ağır ihmale nazaran ağırlaşması esas itibarıyla bu ikinci unsur sebebiyle ortaya çıkmaktadır. Bu konu bir sonraki başlıkta daha yakından değerlendirilmiştir. Yargıtay, Varşova Sözleşmesi m. 25 çerçevesinde verdiği bir kararında, pervasızca davranış kusuru için 'kasta yakın ă̆ır kusur' ifadesini kullanmış ve haklı olarak her ağır kusurun sınırsız sorumluluk için yeterli olmayacağı zannını uyandırmıştır ${ }^{81}$. Ağır ihmal, ağır kusur olarak nitelendirilse de, pervasızca davranış kusurunun kabulü bakımından yeterli değildir. Çünkü öğretide de ifade edildiği üzere;

77 Bu hususta bkz ve karş Kirchhof (n 37) HGB $\$ 435$ N 6; Jesser-Huß (n 3) CMR Art. 29 N 17; Thume, 'Kommentar’ (n 37) HGB $\$ 435$ N 12. Ayrica bkz Otte (n 15) CMR Art. 29 N 9; Ingo Koller, 'HGB $\$ 435$ ' in Ingo Koller, Peter Kindler, Wulf-Henning Roth, Klaus-Dieter Drüen and Nina Bach (eds), Handelsgesetzbuch (9th edn, C.H.BECK 2019) HGB $\$$ 435 N 2; Schaffert (n 37) HGB $\$ 435$ N 7; Bahnsen (n 24) CMR Art. 29 N 13. BGH, Urteil vom 30. 9. 2010 - I ZR 39/09 (OLG Nürnberg), NJW 2011, (296), 298: ‘...besonders schweren Pflichtenverstoß, bei dem sich der Frachtführer und seine Leute in krasser Weise über die Sicherheitsinteressen seiner Vertragspartner hinwegsetzen'. BGH, Urteil vom 22.05.2014 - I ZR 109/13, BeckRS 2014, 20661.

78 Tandoğan (n 33) 54 vd; Eren (n 33) 602; İmre (n 42) 27; Kahraman (n 57) 419; ayrıca bkz Heinrich Honsell, Bernhard Isenring and Martin A. Kessler, Schweizerisches Haftpflichtrecht (5th edn, Schulthess 2013) §6 N 26.

79 Öğretide 'pervasızca davranış' unsurunun ağır ihmal ile aynı olduğu görüşü için bkz Yavaş, 'Kusur Türleri' (n 12) 225; Yavaş, Konteyner (n 39) 220; ayrıca bkz Sözer, Deniz Ticareti (n 63) 298. Alman hukuku bakımından bkz ve karş Thume, 'Kommentar' (n 37) HGB $\$ 435$ N 11-12; Merkt (n 37) HGB $\$ 435$ N 2.

801955 yılı Lahey Protokolü’nün 25. maddesinin müzakerelerinde sınırsız sorumluluk şartlarının ağırlaştırılması görüşünün hâkim olduğu yönünde bkz Özdemir (n 64) 117.

81 Yargitay 11 HD, E 1998/5499 K 1999/136, 26.1.1999 <https://www.kazanci.com.tr/> Erişim Tarihi 26 Temmuz 2021. Değerlendirme için bkz Gençtürk, 'Yeni' (n 26) 133. 
kişinin zarar ihtimalini görebilecek durumda olup da yeterli özeni göstermediği için görememiş olduğu hallerde de ağır ihmal söz konusu olabilir ${ }^{82}$.

Pervasızca davranış, TTK m. 886'nın açık lafzına göre 'olumlu veya olumsuz davranış' (...filitinin veya ihmalinin...) şeklinde ortaya çıkabilir. Yükün güvenliğ̈i, zarara veya hasara uğramaması için hangi güvenlik önlemlerinin ne kapsamda alınması gerektiği, somut olayın şartlarına göre tespit edilir ${ }^{83}$. Taşımayla ilgili risk büyüdükçe, gösterilmesi gereken dikkat ve özen düzeyi de yükselir ${ }^{84}$. Buna uygun olarak Yargıtay 11 HD, İtalya’da taşıma yapan sürücülerin, yol güzergâhının riskli olması nedeniyle, daha fazla özen göstermek ve bu bağlamda yeterli güvenlik önlemlerini almak zorunda oldukları şeklinde karar vermiştir ${ }^{85}$.

Taşımaya konu yükün kolay paraya çevrilebilmesi, bu yönden çalınma tehlikesinin fazla olması, maddi değeri, taşıyıcıya bildirilmesi gereken bir tehlikesinin bulunup bulunmadığı ve sözleşmenin niteliği alınması gerekli önlemlerin neler olduğunun tespitinde ve derecesinde önem taşır ${ }^{86}$. Yükün başka bir araca aktarılmasına ilişkin süreçlerde zarar doğma ihtimali yükselir. Bu sebeple, yükün giriş ve çıkış kontrollerinin doğabilecek zararları önlemek adına uygun bir şekilde organize edilmesi gerekir $^{87}$.

\section{bb. Zararın Muhtemelen Meydana Geleceği Bilinci}

Zarar verenin, sınırsız sorumlu tutulabilmesi için, bir zararın muhtemelen meydana geleceği bilincini taşıması gerekir. Zarar doğacağı bilinci sübjektif bir olgu olduğu için, daha çok bazı işaretlerden, emarelerden ve somut olayın özelliklerinden yola çıkılarak tespit edilebilir ${ }^{88}$. Bu yönden eğer olayda vuku bulan pervasızca davranış, zararın muhtemelen meydana geleceğine ilişkin bir öngörüyü faile dayatıyorsa, ikinci unsurun mevcut olduğu kabul edilir ${ }^{89}$. Dolayısıyla zarar bilinci, pervasızca davranışın taşıyıcıya dayattığı bir öngörüdür. Ancak zarar bilincine, pervasızca davranışın şartlarının oluştuğu hallerde mutlaka sahip olunacağı sonucuna varılamaz ${ }^{90}$. Taşıyıcının pervasızca davranışı,

82 Çağa (n 53) 301; Yazıcıŏlu (n 64) 173.

83 Kirchhof (n 37) HGB $\$ 435$ N 6; Thume, 'Kommentar' (n 37) HGB $\$ 435$ N 13.

84 OLG Düsseldorf Urteil vom 9.10.2002 - 18 U 38/02, https://xn-rabro-mva.de/zur-kontrollpflicht-des-fahrers-eineskuehltransportes/. OLG Zweibrücken (5. Zivilsenat), Urteil vom 12.03.2019 - 5 U 63/18, BeckRS 2019, 4729.

85 Yargitay 11 HD, E 2000/2114 K 2000/3241, 20.04.2000 <https://www.kazanci.com.tr/> Erişim Tarihi 26 Temmuz 2021.

86 Alınması gereken önlemlerin niteliği ve kapsamı belirlenirken göz önünde tutulması gereken ölçütler hakkında bkz ve karş Kirchhof (n 37) HGB $\$ 435$ N 6; Paschke (n 37) HGB $\$ 435$ N 6; Thume, 'Kommentar' (n 37) HGB $\$ 435$ N 13 ; Merkt (n 37) HGB $\$ 435$ N 2.

87 Thume, 'Kommentar' (n 37) HGB $\$ 435$ N 13.

88 Bkz ve karş Paschke (n 37) HGB $\$ 435$ N 7.

89 Bkz ve karş 'Das Bewusstsein von der Wahrscheinlichkeit des Schadenseintritts ist eine sich dem Handelnden aus seinem leichtfertigen Verhalten aufdrängende Erkenntnis, es werde wahrscheinlich ein Schaden entstehen'. Ayrica bkz Merkt (n 37) HGB $₫ 435$ N 2; Schaffert (n 37) HGB $\$ 435$ N 12; Thume, 'Kommentar' (n 37) HGB $\$ 435$ N 14.

90 BGH, Urteil vom 25. 3. 2004 - I ZR 205/01, NJW 2004, 2445 ff; Paschke (n 37) HGB $\$ 435$ N 7; Ralf Wojtek and JudyAnne Krug, 'Haftungsvermeidung im Transportgewerbe' in Christoph E. Hauschka, Klaus Moosmayer and Thomas Lösler (eds), Corporate Compliance Handbuch der Haftungsvermeidung im Unternehmen (3rd edn, C.H.BECK 2016) §56 N 20 . 
içeriği ve vuku bulduğu şartlara bakıldığında, taşıyıcının bu bilince sahip olduğu kabulünü haklı gösteriyorsa, böyle bir çıkarım yapılabilir ${ }^{91}$. Olayların tipik akışı ve hayat tecrübeleri dikkate alınarak pervasızca bir davranıştan, kişinin zarar bilincine sahip olduğu kabul edilebilir ${ }^{92}$. Nitekim Yargıtay ve BAM kararlarında da 'maddi vakıaların oluş şeklinin' bu yönden dikkate alınarak sonuca varıldığı görülmektedir ${ }^{93}$.

TTK m. 886'da failde aranan bilincin 'zararın meydana gelmesi ihtimali’ne ilişkin olacağı hükme bağlanmıştır. Bundan anlaşılması gereken, olayın şartlarına göre zarar doğması riskinin 'muhtemel' olmasıdır. Dolayısıyla burada fail, 'bir zararın muhtemelen meydana geleceği bilinciyle’ pervasızca bir davranışta bulunmalıdır. Benzer hak durumunu düzenleyen TTK m. 1187 bakımından Süzel, hükmün mehazı Lahey-Visby Kuralları m. 4'ü de dikkate alarak, TTK m. 1187'de kullanılan 'ihtimal' ifadesinin isabetli olmadığını, 'muhtemelen zararın meydana geleceği bilinciyle’ şeklinde bir çevirinin tercih edilmesi gerektiğini haklı olarak ifade etmektedir ${ }^{94}$. Bu yönden öğretide anılan unsurun varlığı tespit edilirken davranışın zarara sebebiyet vereceğinin yüzde elli bir ve üzerinde bir olasılık şeklinde öngörüldüğü, bir başka anlatımla zararın ortaya çıkma ihtimalinin çıkmama ihtimalinden daha yüksek olduğu hallerde zararın ortaya çıkmasının muhtemel olduğu ifade edilmektedir ${ }^{95}$. Bu noktada TTK m. 886'da ihtimal bakımından belirli bir oran veya olasılık değerinin aranmamış olduğunu, ayrıca öğretide anılan hususta aksi fikirlerin de bulunduğunu belirtmek gerekir ${ }^{96}$. Ancak pervasızca davranış kusurunun tarihi evrimi ve uluslararası metinlerde kullanılan 'probably' ifadesi dikkate alındığında, zarar olasılığının muhtemel, bir başka anlatımla galip ihtimal (yüzde elli bir ve üzerinde bir olasılık) olması gerektiği sonucuna varılması uygun olur ${ }^{97}$. Nitekim TTK m. 886'nın gerekçesinde de 'zararın muhtemelen gerçekleşebileceği bilinciyle' şeklinde bir ifade kullanılmıştır.

Zarar bilinci bakımından AlmTK $\$ 435$ ile TTK m. 886 arasında bir lafız farkı söz konusudur. AlmTK’de taşıyıcının 'bir zararın (ein Schaden)' meydana gelmesine ilişkin bilincinden bahsedilmişken TTK m. 886'da 'böyle bir zararın' ifadesi kullanılmıştır. Metinde geçen 'böyle bir zarar' ifadesinden yola çıkılarak, somut olayda fiilen gerçekleşen zararın nicelik ve nitelik yönünden öngörülmesi gerektiği sonucuna varılmamalıdır ${ }^{98}$. Hükmün gerekçesinden de, seçilen ifadenin bilinçli olduğu yönünde

91 Bu hususta bkz ve karş BGH, Urteil vom 25. 3. 2004 - I ZR 205/01, NJW 2004, 2445 ff; BGH, Urteil vom 12.1 .2012 - I ZR 214/10 (OLG Düsseldorf), NJW-RR 2012, 367; Paschke (n 37) HGB $\$ 435$ N 7; Wojtek and Krug (n 90) §56 N 20; Federal Mahkeme uygulaması hakkında bkz Klaus Ramming, Hamburger Handbuch Multimodaler Transport (1st edn, C.H.BECK 2011) \$22 N 637.

92 Bu hususta bkz ve karş Paschke (n 37) HGB $\$ 435$ N 7.

93 Yargitay 11 HD, E 2018/3164 K 2019/4721, 24.06.2019: 'Maddi olguya ilişkin iddianın bu biçimdeki ileri sürülüşünün, davalı taşıyıcının pervasızca hareket etmesi nedeniyle hasarın oluştuğuna ilişkin olduğunda duraksanmamalıdır' <https:// www.kazanci.com.tr/> Erişim Tarihi 26 Temmuz 2021. İstanbul 14 BAM E 2018/1237 K 2019/1183, 26/09/2019; İstanbul 14 BAM E 2017/876 K 2018/295, 26/03/2018: 'Bu durumda somut olayın oluşşeklinin, bu yasal düzenlemeye göre değerlendirilmesi gerekir’ <https://emsal.uyap.gov.tr/BilgiBankasiIstemciWeb/> Erişim Tarihi 26 Temmuz 2021.

94 Süzel (n 2) 561.

95 Süzel (n 2) 561; Çağa (n 53) 301; Özdemir (n 64) 119, 113; Yazıcığlu (n 64) 172; Gençtürk ve Yiğit (n 61) 39, Gençtürk, 'Yeni' (n 26) 128; Muharrem Gençtürk, Uluslararası Eşya Taşıma Hukuku (Gecikmeden Doğan Sorumluluk) (1. Bası, Vedat 2006) 242; ayrıca bkz Erdoğan (n 20) 314.

96 Bkz Yavaş, Konteyner (n 39) 222-223.

97 Çağa (n 53) 300-301; Süzel (n 2) 561; Gençtürk, Uluslararası (n 95) 242.

98 Yetiş Şamlı, Sorumluluk (n 12) 98; AlmTK $\$ 435$ bakımından yapılan benzer değerlendirme için bkz ve karş Thume, 
bir sonuç çıkarılması mümkün değildir. Aksini kabul, maddenin uygulanması imkânını ortadan kaldıracağı gibi genel sorumluluk hükümlerindeki anlayışa da uygun değildir ${ }^{99}$.

\section{b. Pervasızca Davranış Kusurunun Niteliği: 'Yeni Bir Bilinçli Ağır İhmal Türü'}

Pervasızca davranış kusuru, pervasızca davranış ve zarar bilinci şeklinde iki unsurdan oluşmaktadır. Failde zarar bilincinin aranması sebebiyle, yukarıda ifade edildiği üzere, öğretide ikinci kusur derecesinin, 'olası kasıt', 'bilinçli ağır ihmal' veya 'bilinçli ihmal' olarak nitelendirildiği görülmektedir. Hemen belirtmek gerekir ki bu kusur türünde aranan şartlar olası kasta nazaran daha hafiftir. Çünkü taşıyıcının öngördüğü zararı kabul etmesi, bir başka anlatımla sonucu dolaylı da olsa istemesi gerekli değildir ${ }^{100}$. Bu nedenle pervasızca davranış kusurunun olası kasıt olarak değerlendirilmemesi gerekir. Ayrıca TTK m. 886'da kasta açıkça yer verildiği için, pervasızca davranış kusurunun yerinin ihmal suretiyle işlenen fiiller bakımından incelenmesi gerekir ${ }^{101}$. Pervasızca davranış kusuru ancak ağır ihmal niteliğindeki fiiller bakımından söz konusu olacağından, bu kusur derecesi için hafif ihmal düzeyinde kalan fiillerin de yeterli olmayacağını eklemek gerekir.

Türk hukukunda, kusurlu davranışın işlenme biçimlerinden biri olan ağır ihmal, failin davranış normunu ihlal ettiğini, bir başka anlatımla hukuka aykırı davrandığını önceden öngörmüş olup olmamasına göre 'bilinçli/şuurlu' ve 'bilinçsiz/şuursuz' ihmal olarak ikiye ayrılır. Buna göre, fail fiilin hukuka aykırı sonuç verebileceği ihtimalini ${ }^{102}$ 'öngörmesine’ rağmen, bunun gerçekleşmeyeceğini 'ümit etmişse', 'bilinçli ihmal' söz konusu olur. Bilinçli ihmal bakımından yapılan diğer tanımlar ise, failin zarara yol açma riskinin bilincinde olmasına rağmen, bunun gerçekleşmeyeceğini varsayması ${ }^{103}$ veya failin zarara yol açma olasılığını öngörmesine rağmen, bunu yeterince dikkate almaması şeklindedir ${ }^{104}$. Bilinçli ihmal, hem ağır ihmal hem de hafif ihmal düzeyinde kalan fiiller bakımından söz konusu olabilir ${ }^{105}$. Buna karşılık, kişi hukuka aykırı bir sonucun meydana geleceğini öngörmemekle birlikte, gerekli özeni gösterseydi öngörebilecek idiyse ‘bilinçsiz ihmal' söz konusu olur ${ }^{106}$. Genel eserlerde, bu ayrımın teorik kaldığı, uygulanma olanağı bulmadığı belirtilmekteyse

\section{'Kommentar' (n 37) HGB $\$ 435$ N 14.}

99 Kasıtla işlenen fiiller bakımından yapılan değerlendirme için bkz Tandoğan (n 33) 47; Oğuzman ve Öz (n 40) N 158.

100 Bkz Gençtürk, 'Yeni' (n 26) 135.

101 Benzer şekilde bkz Sözer, Deniz Ticareti (n 63) 296; Yavaş, Konteyner (n 39) 215; Birinci Uzun (n 61) 196; Yüce (n 26 ) 184 vd.

102 Tekinay, Akman, Burcuoğlu ve Altop (n 40) 495; İmre (n 42) 27; Tandoğan (n 33) 49.

103 Roland Brehm, 'OR Art. 41' in Heinz Hausheer and Hans Peter Walter (eds), Berner Kommentar, Die Entstehung durch unerlaubte Handlungen, Art. 41 - 61 OR, Schweizerisches Zivilgesetzbuch, Das Obligationenrecht (4th edn, Stämpfli 2013) Art. 41 N 197a. Ayrica bkz Honsell, Isenring and Kessler, (n 78) §6 N 31.

104 Karl Oftinger and Emil W. Stark, Schweizerisches Haftpflichtrecht, Erster Band: Allgemeiner Teil (5th edn Schulthess 1995) $\S 5 \mathrm{~N} 110$.

105 Hilmar Neumann, 'Die unbeschränkte Haftung des Frachtführers nach $₫ 435$ HGB' (2002) 11(12) Transportrecht 413, 417. Buna karşılık, bilinçli ihmalin, ağır ihmalin bir türü olduğu ve ağır ihmalin en ağır hali olduğu da öğretide ileri sürülmektedir, bkz Oğuzman ve Öz (n 40) N 160. Çalışmada anlaşılır olması ve ağır ihmale de vurgu yapması bakımından 'bilinçli ağır ihmal' şeklinde bir kullanım tercih edilmiştir.

106 Bilinçli/bilinçsiz ihmal kavramları hakkında bkz Tandoğan (n 33) 49; Eren (n 33) 602; Andreas von Tuhr and Hans Peter, Allgemeiner Teil des Schweizerischen Obligationenrechts Band I (3rd edn Schulthess 1984) 429. 
de ${ }^{107}$, TTK m. 886'da yer alan zarar bilinci, konunun bu ayrım bakımından da incelenmesini gerekli hale getirmiştir.

Öğretide yapılan bilinçli ihmal tanımlarına bakıldığında, failde aranan 'öngörme’ unsurunun bazı kaynaklarda hukuka aykırı davranış, bazılarında hukuka aykırı sonuç, bazılarında ise zararlı sonuç bakımından şart koşulduğu görülmektedir. Her şeyden önce pervasızca davranış kusuru bakımından taşıyıcıda, 'zararın muhtemelen meydana geleceğine ilişkin' bilincin bulunması aranır. Bunun dışında bilinçli ihmalin geleneksel kullanımında fail, aldığı birtakım önlemlere, yeteneklerine veya önceki tecrübelerine dayanarak, öngördüğü sonucun gerçekleşmeyeceğini ümit etmekte; ancak failin aldığı önlemler olayda yetersiz kalmaktadır. Ayrıca bilinçli ihmale ilişkin tanımlarda hukuka aykırı sonucun doğması ihtimalinin yüksek olması gerektiğine özel bir vurgu yapılmaz; failin fiilin hukuka aykırı sonuç verebileceği ihtimalini/olasılığını öngörmesi yeterli görülür ${ }^{108}$. Pervasızca davranış kusurunda ise, davranışın ağırlığı ve olayın şartlarına göre zarar doğması riskinin muhtemel, daha açık anlatımla galip ihtimal olması gerekir. Dolayısıyla pervasızca davranış kusuru, bilinçli ihmalin geleneksel tanımı ile birebir örtüşmeyen bir kusur türüdür ${ }^{109}$. Ancak pervasızca davranışın ağır ihmal niteliğinde bir davranış olması ve maddede aranan zarara ilişkin bilinç sebebiyle pervasızca davranış kusurunun 'yeni bir bilinçli ağır ihmal' olarak nitelendirilmesi mümkündür. Bu nedenle geleneksel kusur ayrımında 'bilinçli ağır ihmal', 'i) basit bilinçli ağır ihmal' ve 'ii) pervasızca davranış kusuru' şeklinde iki alt başlığa ayrılabilir. O halde pervasızca davranış kusuru, olası kasıt ağırlığına ulaşmayan bir kusurdur ve bilinçli ağır ihmalin yeni bir türüdür.

Sınırsız sorumluluğa sebebiyet veren pervasızca davranış kusurunun arka planında 'wilful misconduct' kavramının yer aldığ ifade edilmektedir ${ }^{110}$. Wilful misconduct kavramı, 1955 Lahey Protokolü ile değiştirilmeden önce, 1929 Varşova Sözleşmesỉnin 25. maddesinin İngilizce tercümesinde kullanılmıştır ${ }^{111}$. 1955 Lahey Protokolü ile değiştirilen Varşova Sözleşmesỉnin 25. maddesinde, havayolu taşıyıcısının sorumluluk sınırını kaldıran kusur türleri için, zarar verme kastı veya zararın doğması ihtimali olduğunu bilerek dikkatsizce yapılan bir hareket veya ihmal şeklinde bir tabir kullanılmıştır ve bu yeni düzenlemenin 'wilful misconduct' kavramının açıklaması olduğu konusunda yaygın bir kabul bulunmaktadır ${ }^{112}$. Değişiklik ile amaçlanan, 'wilful misconduct' kavramının ne

107 Eren (n 33) 602; Oftinger and Stark (n 104) §5 N 111.

108 İmre (n 42) 27; Tandoğan (n 33) 49.

109 Pervasızca davranış kusurunun, zarar ihtimalin galip ihtimal olması yönüyle bilinçli ihmalden ayrıldığı, ancak bu iki kusur derecesinin bazı hallerde örtüşebileceği yönünde bkz Gençtürk, 'Yeni' (n 26) 135.

110 Yetiş Şamlı, Geç Teslim (n 64) 170.

111 Kavramın tarihçesi hakkında ayrıntılı bilgi için bkz Damar, 'Wilful Misconduct' (n 56) 380 vd. Kavram hakkında yapılan açıklamalar için bkz ve karş Yetiş Şaml, Sorumluluk (n 12) 90; Kahraman (n 57) 421; Yavaş, 'Kusur Türleri' (n 12) 206; Sözer, Deniz Ticareti (n 63) 294: 'Wilful misconduct bilerek, isteyerek hukuka aykırı davranmaktır; somut olaya göre, failde bir başkasına zarar vermek kastı olabileceği gibi, olmayabilir de, önemli olan fail davranışını hukuka aykırı olduğunu ve bir zarar meydana gelebileceğini bilmektedir, buna rağmen davranışını sürdürmektedir'. Erdoğan, Birleşik Krallık'ta verilen farklı yüksek mahkeme kararlar neticesinde kavramın 'taşıyıcının hatal veya yanlış olduğunu bilerek gerçekleştirdiği eyleminin, zarar meydana getirme olasılığıı artırdığını bilincinde olması' şeklinde tanımlanabileceğini ifade etmektedir (Erdoğan (n 20) 280 vd, ayrıca bkz 277, 280, 282); ayrıca bkz Malcolm Clarke, 'Wilful misconduct under English law', (2016) 21(4) Uniform Law Review, 574, $574 \mathrm{ff}$.

112 Damar, 'Wilful Misconduct' (n 56) 383; Duygu Damar ve Kübra Yetiş Şamlı, Milletlerarası Taşıma Hukuku’nda ve Yeni Türk Ticaret Kanunu’nda "Pervasizca Hareket" (Wilful Misconduct) Kusuru (1. Bası, Deniz Hukuku Derneği-Sigorta 
olduğunun araştırılmasından ziyade artık mahkemelerin somut olayın şartlarını, maddede belirtilen kıstaslar çerçevesinde değerlendirmeleridir ${ }^{113}$.

TTK m. 886’nın gerekçesinde hükme kaynaklık ettiği ifade edilen AlmTK $\$ 435$ ’in kaleme alınmasında da Varşova Sözleşmesi'nin değişik 25. maddesi etkili olmuştur ${ }^{114}$. Bu tarihi gelişim içerisinde, pervasızca davranış kusurunun mevcut olup olmadığının TTK m. 886'da belirtilen unsurlar bakımından değerlendirilmesi ve şartların gerçekleşmesi halinde sınırsız sorumluluk esasının geçerli olacağının kabulü uygun bir yaklaşım olacaktır. Öğretide de ileri sürülen bu düşünceye üstünlük tanımak gerekir ${ }^{115}$. Bu şekilde CMR m. 29 bakımından kasta eş değer kusurun belirlenmesinde uluslararası konvansiyonlarda tercih edilen pervasızca davranış kusuru esas alınmış olacak ve bu da sınır aşan taşımalarda uygulama birliğinin oluşmasına katkı sağlayacaktır ${ }^{116}$.

Netice itibarıyla 'pervasızca ve zararın muhtemelen meydana geleceği bilinci ile davranış' şeklinde ifade edilebilecek ikinci kusur derecesi, Türk hukukunda yapılan ayrıma göre mevcut kusur derecelerinden birine girmemektedir. Pervasızca davranış kusuru, olası kasıt ağırlığına ulaşmayan, yeni bir bilinçli ağır ihmal türüdür. Bu sebeple anılan kusur türünün kanunda yer alan unsurları ile değerlendirilmesi ve yukarıda yapılan açıklamalar sşığında içeriğinin doldurulması gerekir. Ayrıca kusurun şartlarının, sadece ağır ihmalin yeterli görüldüğü 6762 sayılı TTK dönemine nazaran ağırlaştırıldığının ve taşıyıcının sınırsız sorumluluğuna yol açan hallerin kapsamının daraltıldığının da son olarak eklenmesi gerekir.

\section{MAHKEME KARARLARI}

Bu başılı altında esas itibarıyla konuyla alakalı mahkeme kararları ortaya konulmuş ve kararlara yansıdığı ölçüde sabit görülen vakıalara ilişkin değerlendirmeler yapılmıştır. Mahkeme kararlarına bakıldığında, kasta nazaran pervasızca davranış kusurunun daha büyük pratik önemi haiz olduğu görülmektedir.

\section{A. KASITLA işLENEN FiiLLER}

Kasıtlı fiillere verilecek örnekler oldukça az olup, yükün taşıyıcı veya yardımcıları tarafından çalınması buna misal olabilir ${ }^{117}$. Bu sebeple Yargıtay'ın önüne gelen taşıyıcının çalışanları tarafından

Hukuku Derneği 2012) 9. Resmi çeviri için bkz RG 03.12.1977/16128. Bu şekildeki resmi çevirinin eleştirisi ve çeviri önerisi için bkz Çağa (n 53) 300-301.

113 Damar, 'Wilful Misconduct' (n 56) 384.

114 Yavaş, Konteyner (n 39) 203; Adıgüzel, 'CMR' (n 13) 360.

115 Bu kusur derecesinin iç hukukta yerleşik kusur kavramlarından bağımsız olarak ve kanunda belirtilen unsurların varlığı veya yokluğu araştırılarak belirlenmesi gerektiği yönünde bkz Gençtürk, 'Yeni' (n 26) 134; TTK m. 1187 bakımından Süzel (n 2) 558-559; Varşova Sözleşmesi m. 25 bakımından ayrıca bkz Yetiş Şamlı, Sorumluluk (n 12) 96.

116 Gençtürk, 'Yeni' (n 26) 140.

117 Örnek için bkz Kirchhof (n 37) HGB $\$ 435$ N 4; ayrıca bkz Özdemir (n 64) 111. TTK m. 1187’de öngörülen zarara kasten sebebiyet verilmesi bakımından en tipik örneğin baratarya olduğu yönünde bkz Süzel (n 2) 557. 
gerçekleştirilen hırsızlık olayında, 'kasta yakın bir davranış veya pervasızca bir tutum'dan değil ${ }^{118}$, kasıttan bahsedilmesi gerekir. Yargıtay'ın bir başka kararında, daha önce yaptığı taşımalar sebebiyle kendisine ödenmeyen taşıma ücretini tahsil edemediği için emtiayı bilerek ve isteyerek gönderilene teslimden kaçınan kişinin kasıtlı davrandığ 1 kabul edilmiştir ${ }^{119}$.

\section{B. PERVASIZCA DAVRANIŞ KUSURUYLA işLENEN FiliLER}

\section{TTK M. 886 Bakımından Verilen Kararlar}

6102 sayılı TTK m. 886’nın uygulanmasına ilişkin Yargıtay ve BAM kararlarında, bazen ağır kusur ifadesinin kullanıldığ ${ }^{120}$; bazen pervasızca davranış, zararın meydana geleceği bilinci şeklindeki kanuni ifadenin tercih edildiği görülmektedir ${ }^{121}$. Ağır kusur-hafif kusur ayrımında, ağır kusur ile kastedilen genellikle 'ağır ihmal'dir ${ }^{122}$. Ağır kusur kavramı içerisine kasıt da dâhil edilebilir. Pervasızca davranış kusuru, failin zararın muhtemelen meydana geleceği bilinciyle işlediği ağır ihmal niteliğindeki fiiller bakımından söz konusu olur. Bu nedenle böyle bir bilincin mevcut olmadığ1 ağır ihmal düzeyinde kalan fiiller, 6762 sayılı Kanun döneminden farklı olarak, artık bu kapsamda değerlendirilemez. Bunun dışında belirtmek gerekir ki pervasızca davranış kusurunun unsurlarının ayrıntılı olarak tartışıldı̆̆ı bir karar tespit edilememiştir.

118 Yargitay 11 HD E 2009/12640 K 2011/5061, 26.4.2011 <https://www.kazanci.com.tr/> Erişim Tarihi 26 Temmuz 2021.

119 Yargıtay 11 HD E 2015/3257 K 2016/1189, 09.02.2016 <https://www.kazanci.com.tr/> Erişim Tarihi 26 Temmuz 2021.

120 İstanbul 13 BAM, E 2019/1699 K 2019/1383, 16.10.2019: 'Doktrinde “isteyerek kötü harekete eşdeğer sayılan kusur" kavramı, "ağır kusur" veya "ağır ihmal" olarak yorumlanmaktadır. TTK 886. madde düzenlemesindeki "pervasızca hareket" kavramı da bu kıstaslar çerçevesinde ele alındığında, taşıyıcı veya yardımcılarının yükün güvenliği ile ilgili hususları açıkça önemsemeden hareket etmesi olarak karşımıza çıkmaktadır'; İstanbul 12 BAM E 2019/567 K 2019/1065, 09.09.2019: 'TTK nun 882.maddesi uyarınca taşıyanın sorumluluğu kural olarak sinırl sorumluluk ise de; TTK 886. madde gereği zarara kasten veya pervasızca bir davranışla ve böyle bir zararın meydana gelmesi ihtimalinin bilinciyle işlenmiş bir fiilinin veya ihmalinin sebebiyet verdiği hallerde taşıııcı sorumluluk sınırlamalarından yararlanamaz. Adreste teslim esaslı bir kargonun alıcının telefonla yönlendirdiği iddia olunan kişiye herhangi bir kimlik örneği alınmadan yapılan teslimin pervasızca bir davranış olarak kabulü gerekmektedir. Taşıyıcının telefonla gelen bildirimin doğruluğunu araştırmadan teslimde ağır kusurlu sayılması gerektiği, kargo sorumluluk belgesinde cihazın niteliğinin açıkça yazılı olduğu anlaşılmakla davalı taşıyıcının tam sorumluluk esasına göre sorumlu tutulmasında isabetsizlik yoktur'. İstanbul 14 BAM, E 2018/1237 K 2019/1183, 26.09.2019: 'TTK'nın 886. madde düzenlemesindeki "pervasızca hareket” kavramı..., taşıyıcı veya yardımcılarının yükün güvenliği ile ilgili hususları açıkça önemsemeden hareket etmesi olarak karşımıza çıkmaktadır...TTK'nın 885. maddede düzenleme bulan ağır kusur ya da pervasızca ve zarar meydana gelmesi ihtimalinin bilinciyle yapılan bir ihmal ya da hareket olarak kabul edilmesi gerektiği anlaşılmaktadır'; İstanbul 43 BAM, E 2020/116 K 2020/354, 27.11.2020: 'Nitekim yasa koyucunun amacı ve uygulamaya bakıldiğında, pervasızca hareket veya ağır kusur, kastla ve kasta yakın düzeyde bir eylemle zarara sebebiyet verilmesi olarak karşımıza çıkmaktadır’; Bakırköy 2 Asliye Ticaret Mahkemesi, E 2017/822 K 2018/254, 19.03.2018: 'Pervasızca davranış kusurundan söz edebilmesi için taşıyıcının veya adamlarının eşya-emtiaya özen yükümlülüğünü düşüncesizce, hareketin şekliyle ilgili olarak "makul bir taşıyıcıdan önlemlere, öngörülen kurallar ve doğabilecek olumsuz sonuçlara aldırmaksızın” yoğun ve ağır ihmal olması gerekmektedir' <https://emsal.uyap.gov.tr/ BilgiBankasiIstemciWeb/> Erişim Tarihi 26 Temmuz 2021.

121 Yargitay 11 HD, E 2018/1009 K 2019/6702, 24.10.2019: 'İlk Derece Mahkemesince, ....taşıma sürecinde pervasızca-zarar meydana gelme bilinci içinde hareket edildiği, üç yıllık zamanaşımının uygulanacağı, davalı tarafin kusurundan bu olayın meydana geldiği, davacı sigortalının herhangi bir kusurunun bulunmadiğı, dolayısıla davalı tarafin meydana gelen zararın tamamından sorumlu olduğu gerekçesi ile davanın kabulüne karar verilmiştir. Bölge Adliye Mahkemesi tarafından...davalı vekilinin istinaf başvurusunun...esastan reddine karar verilmiştir....Bölge Adliye Mahkemesi kararının onanmasına karar vermek gerekmiştir'<https://www.kazanci.com.tr/> Erişim Tarihi 26 Temmuz 2021.

122 Tandoğan (n 33) 54. 
Taşıyıcının sorumluluğu bakımından hırsızlık ve yağma, mahkemelerin sıklıkla önüne gelen olay grupları arasındadır. Aşağıda ayrı ayrı belirtilmiş yargı kararları genel bir değerlendirmeye tâbi tutulduğunda; sürücünün güvenlik görevlisi bulunmayan, kamera veya güvenlik sistemleri ile kontrol edilmeyen, ışıklandırılması olmayan, karanlık, fark edilmesi kolay olan, hırsızlık ve gasp olaylarının yoğun olduğu veya daha evvel yaşandığı alanlarda, devriye kontrolü yapılmayan otoyollarda mola vermesi, yükün yer aldığı kısmın kilitli olmaması veya taşınan eşyanın niteliğine uygun güvenlik önlemlerine sahip olmaması, ikinci bir şoförün veya muavinin bulunmaması, moladan sonra aracın kontrol edilmemesi, araçta küresel konumlama sistemi (GPS), alarm sistemi gibi herhangi bir elektronik/teknik güvenlik tedbirinin ve takip sisteminin olmaması hırsızlık ile yağma olaylarında kusurun değerlendirilmesinde dikkate alınan hususlar olarak göze çarpmaktadır. Olayların ekseriyeti sürücülerin dinlendiği veya aracın başından ayrıldığı esnada ve gece vakti gerçekleşmektedir. Hırsızlık olaylarının gerçekleşmesinin kolaylaştığı bu zamanlarda, sürücüler yükün güvenliğini sağlamak için gerekli önlemleri almakla yükümlüdür.

Örneğin; kargo taşıması yapan sürücünün, aracını saat 01.15 sularında otoyol üzerine park edip uyuduğu, 04.30 sularında uyanıp yola devam ettikten sonra uyarılması üzerine araçtaki pirinçlerin çalınmış olduğunu tespit ettiği, güvenlik kamerasının, görgü şahidinin ve kapı kilidinin bulunmadığı olayda, TTK m. 886'nın şartlarının oluştuğu yönünde karar verilmiştir ${ }^{123}$. Söze konu daire kararı, çoğunlukla alınmış ve karara bir muhalefet şerhi düşülmüştür. Muhalefet şerhine bakıldığında, taşınan emtianın kaybına, kimliği belirsiz kişilerin hırsızlık eyleminin yol açtığı, taşıyıcının ise söz konusu eyleme aslen veya fer’an bir iştirakinin, yani kasıtlı bir eyleminin söz konusu olmadığı, hırsızlık gibi kasıtlı ve suç sayılan bir eylemin işlenebileceğinin öngörülmemiş olduğu, bu konuda bilinçli hareket edilmediği, kasta eş değer kusurlu bir hareketin bulunmadığı gerekçesiyle muhalif kalındığı görülmektedir.

CMR m. 29'da kullanılan 'kasta eş değer kusur', kastla aynı kınanma seviyesine sahip davranışı değil; kendisine kasıtlı davranışın hüküm ve sonuçlarının bağlandığı kusur derecesini ifade eder ${ }^{124}$. Belirlemede esas alınacak hüküm TTK m. 886'dır ve bu hükümde öngörülen ikinci kusur derecesinin gerçekleştiğinin tespiti bakımından pervasızca davranış ve zararın muhtemelen meydana geleceği bilincinin mevcudiyeti şüphesiz ayrı ayrı aranacaktır. Zarara ilişkin bilinç, içsel bir unsur olduğu için, burada failin pervasızca davranışının kendisine muhtemelen bir zarar doğacağına ilişkin bilinci dayatıp dayatmayacağı dikkate alınır. Değerlendirme yapılırken, genel hayat tecrübelerine ve olayların normal seyrine bakılır. Belirtilen karara bakacak olursak, kararda geçen verilere göre olayda hırsızlık hadisesini engellemek adına hiçbir önlem alınmamıştır. Sürücünün zarar bilincine

123 Yargitay 11 HD, E 2016/5629 K 2017/4303, 13.09.2017 <https://www.kazanci.com.tr/> Erişim Tarihi 26 Temmuz 2021. Hırsızlık ve yağma olayları bakımından şu davranışlar da ilgili mahkeme tarafından kusur yönünden sınırsız sorumluluğun şartlarını oluşturacak ağırlıkta görülmüştür: Aracın güvenli bir parka değil, korunaksız yol kenarına park edilerek başından uzaklaşılması (İstanbul 13 BAM, E 2018/1403 K 2019/1882, 25.12.2019; benzer şekilde İstanbul 13 BAM E 2018/1115 K 2019/1409, 16.10.2019); kolaylıkla kaçırılması mümkün olan aracın gece vakti güvenliksiz, etrafı açık bir alana park edilmesi (İstanbul 14 BAM E 2018/1237 K 2019/1183, 26.09.2019); hırsızlık ihtimalinin yüksek olduğu, güvenlik önlemlerinin bulunmadığı boş bir arsada aracın park edilmiş olması (İstanbul 14 BAM, E 2017/876 K 2018/295, 26.03.2018). Kararlar için bkz <https://emsal.uyap.gov.tr/BilgiBankasiIstemciWeb/> Erişim Tarihi 26 Temmuz 2021.

124 Bu hususta bkz ve karş Yetiş Şamlı, Sorumluluk (n 12) $41 \mathrm{vd.}$ 
sahip olduğunun kabulü için, mutlaka hırsızlık olayına iştirak etmesi ve bunu istemesi, bir başka anlatımla kusurun kasıt derecesine ulaşması gerekmez. Bu açıdan özel dairece çoğunluk tarafından benimsenen yaklaşım isabetlidir.

Sınırsız sorumluluğa yol açan bir başka durum 'ağır organizasyon kusuru' olarak nitelendirilen özellikle eşyanın kaybolduğu yere ve kayıp nedenine ilişkin hiçbir açıklama getirilemeyen hallerdir. Taşıyıcının işletmesini faaliyetlerine uygun olarak organize etmemesi ve kaybın nedenini açılayamaması halinde prensip olarak pervasızca davranış kusurunun var olduğu kabul edilmelidir ${ }^{125}$. Özellikle yükün depodan bir araca veya bir araçtan diğerine aktarılması sırasında gerekli kontrollerin uygun şekilde yapılmaması halinde prensip olarak taşıyıcının nitelikli kusurunun olduğu sonucuna varılır; çünkü aktarmalar yükün kayıp riskinin arttığı süreçlerdir; bu nedenle yükün kaybolmaması için alınması gereken temel tedbirlere uyulmamış olması bir yandan pervasızca davranış teşkil eder, diğer taraftan taşıyıcıda bir zarar bilincinin olduğunu gösterir ${ }^{126}$. Yargıtay 11 HD, 6762 sayılı TTK’nin meri olduğu dönemde CMR m. 29 bakımından verdiği bir kararında taşıyıcının zarar nedeni hakkında hiçbir açıklama yapmamış olmasının, kendisinin sorumluluğunu sınırlama hakkını karine olarak kaybetmiş sayılmasına yol açacağı şeklinde içtihat etmiştir ${ }^{127}$.

Organizasyon kusuru bağlamında mahkemelerin önüne sıkça gelen olay grubu gönderinin kaybolmasıdır. Kararlara bakıldığında kargo taşımacılığında gönderinin tamamen kaybolması ${ }^{128}$, yirmi dört saat içinde taşınması gereken bozulabilecek sağlık malzemesinin taşınmaması ve on günlük süre boyunca nerede olduğunun bilinmemesi ${ }^{129}$, kayba ilişkin bir açıklama getirilememesi ${ }^{130}$, kargo paketinin, alıcısına teslim edildiğine ilişkin bir belge sunulamaması ${ }^{131}$, alıcının telefonla yönlendirdiği iddia olunan kişiye herhangi bir kimlik örneği alınmadan malın teslimi ${ }^{132}$, TTK m. 868 hükmüne aykırı emir ve talimatlarla boşaltma adresinin değiştirilmesi ${ }^{133}$, emtianın alıcıya veya göndericiye teslim edilmeyip hurda deposuna atılmas1 ${ }^{134}$ sınırsız sorumluluk için yeterli

125 Alman hukuku bakımından yapılan değerlendirmeler için bkz ve karş Thume, 'Kommentar' (n 37) HGB $₫ 435$ N 21.

126 Alman hukuku bakımından yapılan değerlendirmeler için bkz ve karş Paschke (n 37) HGB, § 435 N 9-10.

127 Yargitay 11 HD, E 2005/12435 K 2006/12818, 5.12.2006; Yargitay 11 HD, E 2004/6554 K 2005/3212, 4.4.2005; Yargitay 11 HD, E 2000/4546 K 2000/5446, 12.6.2000 <https://www.kazanci.com.tr/> Erişim Tarihi 26 Temmuz 2021.

128 İstanbul 14 BAM, E 2018/926 K 2019/66, 17.01.2019 <https://emsal.uyap.gov.tr/BilgiBankasiIstemciWeb/> Erişim Tarihi 26 Temmuz 2021.

129 Yargıtay 11 HD, E 2015/14400 K 2016/3967, 11.04.2016 (Fatih Aydoğan, 'Taşıma Hukukuna İlişkin Güncel Bazı Kararların Değerlendirilmesi’ iç Abuzer Kendigelen, Nurgül Yıldız, İsmail Cem Soykan, Necdet Uzel ve Müge Evlek (edr), Yürürlüğünün 6. Yllında ve Yargıtay Kararları Işı̆̆ında Türk Ticaret Kanunu Sempozyumu (Tebliğler - Tartışmalar) 12 Ekim 2018 (On İki Levha 2018) 245.

130 Yargitay 11 HD, E 2016/7146 K 2018/647, 25.01.2018; Yargitay 11 HD, E 2016/12462 K 2018/4064, 29.05.2018; Yargitay 11 HD, E 2017/3486 K 2019/552, 21.01.2019; Yargitay 11 HD, E 2019/3479 K 2020/1916, 24.2.2020 <https://www. kazanci.com.tr/> Erişim Tarihi 26 Temmuz 2021.

131 Yargitay 11 HD, E 2016/10736 K 2018/2870, 18.04.2018 <https://www.kazanci.com.tr/> Erişim Tarihi 26 Temmuz 2021.

132 İstanbul 12 BAM, E 2019/567 K 2019/1065, 09.09.2019 <https://emsal.uyap.gov.tr/BilgiBankasiIstemciWeb/> Erişim Tarihi 26 Temmuz 2021.

133 Yargitay 11 HD, E 2018/1009 K 2019/6702, 24.10.2019 <https://www.kazanci.com.tr/> Erişim Tarihi 26 Temmuz 2021.

134 İstanbul 12 BAM, E 2019/910 K 2020/215, 18.02.2020 <https://emsal.uyap.gov.tr/BilgiBankasiIstemciWeb/> Erişim Tarihi 26 Temmuz 2021. 
kabul edilmiştir. Yargıtay eski tarihli kararlarında yükün meçhul kişilere teslimini ağır kusur olarak nitelendirmiştir ${ }^{135}$.

Emtianın, otogar gibi pek çok aracın giriş, çıkış ve manevra yaptığı bir yere bırakılmasınınn ${ }^{136}$, bilgisayar monitörlerinin kusurlu (delik) konteynerle taşınmasının ${ }^{137}$ sınırsız sorumluluğun şartlarını oluşturacağı; buna karşılık taşıma sırasında eşyanın olağan şekilde hasarlanmasının bu açıdan yeterli olmayacağı kabul edilmiştir ${ }^{138}$.

\section{CMR M. 29 Bakımından Verilen Kararlar}

CMR m. 29'da yer alan kasta eş değer kusur, iç hukukta TTK m. 886'da hükme bağlanan pervasızca davranış kusuruna göre belirlenmelidir. Bununla birlikte, kararlarda geçen tarihler itibarıyla 6102 sayılı TTK'nin uygulanacağı tahmin edilen olaylar bakımından da bazı kararlarda TTK m. 886'ya atıf yapılmadığı, 'ağır kusur' ifadesinin kullanıldığı görülmektedirr ${ }^{139}$. Daha evvel ifade edildiği üzere ağır kusur, zarar bilinci içermeyen ağır ihmali de içine alan bir kavram olduğundan, bu kullanımın TTK m. 886'ya uygun olmadığı ifade edilmelidir. 6102 sayılı TTK’nin yürürlüğe girmesiyle birlikte, CMR m. 29'da yer alan kasta eş değer kusur için ağır ihmalin yeterli görülmemesi, bundan sonra yukarıda uygulanma şartları izah edilen 'pervasızca davranış kusuru’nun ölçüt alınması gerekir.

Kararlara bakıldığında, eksik teslimin makul bir izahının yapılamaması ${ }^{140}$, taşıma sürecinde yapılan aktarmalar sonrası son teslimat öncesi hatalı istif ve sabitlemeden dolayı hasara yol açılması ${ }^{141}$, vesaikin ibrazı sağlanmadan malın teslimi ${ }^{142}$ sınırsız sorumluluk bakımından yeterli görülmüştür.

Hırsızlık ve gasp olayları bakımından giriş çıkışı denetlenmeyen, kamera ve benzeri güvenlik sistemi olmayan, bekçisi bulunmayan bir tır parkında akşam saatlerinden sabaha kadar mola verildiği, araç sürücüsünün tırın içinde dinlenirken hırsızlık olayının yaşandığı, sürücünün sabah uyandığında

135 Yargitay 11 HD, E 778 K 4782, 6.6.1994. Karar için bkz Gönen Eriş, Açıklamalı-Gerekçeli-Içtihatlı Taşıma Hukuku (6102 Sayılı Türk Ticaret Kanununa Göre) (1. Bası, Seçkin 2015) 276.

136 Yargitay 11 HD, E 2018/3164 K 2019/4721, 24.06.2019 <https://www.kazanci.com.tr/> Erişim Tarihi 26 Temmuz 2021.

137 İstanbul 12 BAM E 2017/524 K 2018/124, 15.02.2018 <https://emsal.uyap.gov.tr/BilgiBankasiIstemciWeb/> Erişim Tarihi 26 Temmuz 2021.

1386762 sayılı Kanun'un uygulandığı bu karar için bkz Yargıtay 11 HD, E 2014/9550 K 2014/16834, 4.11.2014 <https://www. kazanci.com.tr/> Erişim Tarihi 26 Temmuz 2021.

139 Yargitay 11 HD, E 2018/4570 K 2019/6098, 02.10.2019: 'CMR 29. maddesi hükmüne göre, ağır kusurun varlı̆g halinde taşıyıcı, bu konvansiyonun taşıyıcının sorumluluğunu kaldıran, sinırlayan veya ispat yükünü diğer tarafa yükleyen hükümlerinden yararlanamayacaktır'; Yargitay 11 HD, E 2018/2624 K 2019/3941, 20.05.2019 künyeli kararda 'taşıyıcının (şoförün) emtianın çalındığı yerin seçiminde gerekli özeni göstermediğinden ağır kusuru bulunduğundan...' şeklindeki ilk derece mahkemesi kararında bir isabetsizlik görülmemiştir <https://www.kazanci.com.tr/> Erişim Tarihi 26 Temmuz 2021.

140 Yargitay 11 HD, E 2014/7 K 2014/10266, 2.6.2014; Yargitay 11 HD, E 2000/4546 K 2000/5446, 12.6.2000; Yargitay 11 HD, E 2004/6554 K 2005/3212, 4.4.2005 <https://www.kazanci.com.tr/> Erişim Tarihi 26 Temmuz 2021.

141 Yargitay 11 HD, E 2015/11711 K 2016/8566, 01.112016 <https://www.kazanci.com.tr/> Erişim Tarihi 26 Temmuz 2021.

142 Yargitay 11 HD, E 2015/8036 K 2016/2783, 14.03.2016 <https://www.kazanci.com.tr/> Erişim Tarihi 26 Temmuz 2021. Buna karşılık eski tarihli bir karar ise aksi yöndedir: Yargıtay 11 HD, E 2000/8660 K 2000/8576, 6.11.2000, karar için bkz Engin Erdil, Karayolu ile Uluslararası Eşya Taşıma Hukuku (3. Bası, Seçkin 2020) 562 vd. 
hırsızlığı fark ettiği olayda ${ }^{143}$ ve İtalya Piacenzo'da seyir halinde iken şoförün on beş dakikadan beri bir arabanın kendisini takip etmekte olduğunu, sonrasında bu aracın polis işaret çarkı ile yanında durduğunu fark etmesi üzerine aracını herhangi bir tedbir almadan güvenlik șeridinde durdurması sonucu gerçekleşen gasp olayında ${ }^{144} \mathrm{CMR}$ m. 29’un şartlarının oluştuğu kabul edilmiştir.

Buna karşılık sürücünün saat 24.00 sularında İngiltere'deki alıcının deposuna geldiği, işyerinin kapalı olması nedeniyle aracını sıra bekleyen tırların arkasına çektiği, sabah bir kişinin aracın camına vurarak sürücüye arka tarafı gösterdiği, anahtarı alarak araçtan çıkan sürücüyü olay yerindeki ikinci şahsın iterek yere düşürdüğü, bu sırada anahtarın elinden çıtığı, anahtarı alan şahsın araç içine girerek aracı çalıştırdığı, olayı engellemeye çalışan sürücünün araçtan düşerek yaralandığ içindeki emtialarla birlikte aracın zayi olduğu olayda kasta eş değer kusur bulunmadığı ${ }^{145}$, aracın teknik kontrolünün yeterli yapılmaması ve aracın balatasının 1 sınması sonucunda yanması ${ }^{146}$, trafik kazasına karışma ${ }^{147}$ veya salt hasarlı teslim ya da hatalı istifleme ${ }^{148}$ olaylarında sınırsız sorumluluğun şartlarının oluşmadığı yönünde karar verilmiştir.

Yargıtay bir kararında ${ }^{149}$, trafik kazasının araç sürücüsünün yüzde yüz kusuru ile meydana geldiği bir olayda, sınırsız sorumluluğun şartlarının oluşmadığına hükmetmiştir. Anılan içtihat yüzde yüz kendi kusuru ile hareket eden kişinin, zarar olasılığını hiçe saymış, zararlı sonucu göze alarak kural ihlali yapmış olduğu gerekçesiyle öğretide eleştirilmiştir ${ }^{150}$. Oysa trafik kazalarında söz konusu olan kusur oranı, kusur derecesini/ağıllı̆ını göstermez ${ }^{151}$. Kusur oranı fiil ile zararlı sonuç arasındaki illiyet bağına ilişkin bir değerlendirme içerir ${ }^{152}$. Örneğin; bir trafik kazasına tek başına sebebiyet veren araç sürücüsü yüzde yüz kusurlu sayılırken, kusurunun ağırlığ hafif ihmal düzeyinde kalabilir ${ }^{153}$. Bu durumda yukarıda izah edildiği üzere, pervasızca davranış kusurunun şartları oluşmaz. Dolayısıyla ilgili Yargıtay kararının salt taşıyıcının kusur oranının yüzde yüz olması sebebiyle isabetsiz olduğu sonucuna varılması mümkün değildir ${ }^{154}$.

143 Yargitay 11 HD, E 2018/4570 K 2019/6098, 02.10.2019 <https://www.kazanci.com.tr/> Erişim Tarihi 26 Temmuz 2021. Hırsızlık olaylarına örnekler için ayrıca bkz Yargıtay 11 HD, E 2018/2624 K 2019/3941, 20.05.2019; Yargıtay 11 HD, E 2015/9172 K 2016/2407, 03.03.2016 <https://www.kazanci.com.tr/> Erişim Tarihi 26 Temmuz 2021.

144 İstanbul 13 BAM, E 2019/1699 K 2019/1383, 16.10.2019 <https://emsal.uyap.gov.tr/BilgiBankasiIstemciWeb/> Erişim Tarihi 26 Temmuz 2021.

145 Yargitay 11 HD, E 2015/7926 K 2016/3438, 29.03.2016 <https://www.kazanci.com.tr/> Erişim Tarihi 26 Temmuz 2021.

146 Yargıtay 11 HD, E 453 K 7005, 30.04.2012. Bkz Eriş (n 135) 807.

147 Yargitay 11 HD, E 602 K 2082, 5.02.2008. Bkz Eriş (n 135) 299.

148 Yargitay 11 HD, E 2005/9206 K 2006/10203, 12.10.2006 <https://www.kazanci.com.tr/> Erişim Tarihi 26 Temmuz 2021; Yargitay 11 HD, E 2012/428 K 2013/1961, 06.02.2013; Yargitay 11 HD, E 2008/11391 K 2010/1942, 22.02.2010. Bkz Erdil (n 142) $530 \mathrm{vd}, 542 \mathrm{vd}$.

149 Yargitay 11 HD, E 2012/429 K 2013/577, 14.1.2013. Bkz Erdil (n 142) 532 vd.

150 Erdoğan (n 20) 320.

151 Kahraman (n 57) 420.

152 ibid 420.

153 ibid 420.

154 Yargitay 11 HD, E 2007/12693 K 2009/7793, 25.6.2009 <https://www.kazanci.com.tr/> Erişim Tarihi 26 Temmuz 2021; İstanbul 12 BAM, E 2018/646 K 2019/1675, 31.12.2019; İstanbul 12 BAM, E 2018/635 K 2019/130, 07.02.2019 <https:// emsal.uyap.gov.tr/BilgiBankasiIstemciWeb/> Erişim Tarihi 26 Temmuz 2021. 


\section{ISPAT YÜKÜ}

TTK m. 886 anlamında sınırsız sorumluluğun şartlarının oluştuğunu, talep sahibi ispat etmekle yükümlüdür ${ }^{155}$. Olayda ikinci kusur derecesinin mevcut olup olmadığı değerlendirilirken, söz konusu pervasızca davranışın taşıyıcıya, zararın muhtemelen doğacağına ilişkin bir bilinci dayatıp dayatmadığı incelenecektir. Bu nedenle talep sahibi, taşıyıcının pervasızca davrandığına ve zararın muhtemelen doğacağının bilincinde olduğuna ilişkin somut olay, olgu ve emareleri hâkime sunmakla yükümlüdür. Yargıtay, maddi olguların ileri sürülüş biçiminden olayda ikinci kusur derecesinin varlığının kabul edilebileceği yönünde karar vermiştir ${ }^{156}$. Uygulamada ayrıca haklı olarak kazanın oluşumunda sürücünün yüzde yüz kusurlu olmasının, onun pervasızca davranış kusuru ile hareket ettiğini göstermeyeceği ifade edilmektedir ${ }^{157}$.

\section{SONUÇ}

Karayoluyla eşya taşımalarında taşıyıcının sorumluluğunu gerektiren zararlar bakımından tazminat yükümlülüğünün belirli bir miktarla sınırlandırılması esası kabul edilmiştir. Ancak TTK m. 886’ya göre, taşıуıсı 'zarara, kasten veya pervasızca ve böyle bir zararın meydana gelmesi ihtimalinin bilinciyle sebep olursa', sorumluluk sinırlamalarından yararlanamaz. Öngörülen nitelikli kusur hallerinin bulunduğu durumlarda, taşıyıcının sınırlı sorumlu tutulması haklı görülmemiştir. Maddenin uygulanması bakımından 'i) kasıtlı veya ii) pervasızca ve zararın muhtemelen meydana geleceği bilinci ile hareket' şeklinde iki kademeli kusurlu davranış ölçütü getirilmiştir. Alternatifli olarak öngörülen bu iki kusur türünden birinin mevcudiyeti ayrıca zamanaşımı sürelerinin de uzamasına yol açmaktadır.

Dolaylı ve doğrudan kasıt ile kastın en ağır hali olan zarar verme saikiyle gerçekleștirilen fiiller ' $k a s ı t$ ' kapsamında değerlendirilir. Pervasızca davranış kusuru bakımından ' $i$ ) pervasızca bir davranış ve ii) zararın muhtemelen meydana geleceği bilinci’nin bir arada bulunması gerekir. Pervasızca davranış, taşıyıcı veya yardımcılarının sözleşme tarafının yükün güvenliğine ilişkin çıkarlarını açık bir şekilde

155 'Davacı, zarara davalının kasten veya pervasızca bir davranışla ve böyle bir zararın meydana gelmesi ihtimalinin bilinciyle işlenmiş bir fiilinin veya ihmalinin sebebiyet verdiğini de iddia ve ispat etmemiştir' (Yargıtay $11 \mathrm{HD}, \mathrm{E} 2015 / 2501 \mathrm{~K}$ 2015/7524, 02.06.2015). Ayrica bkz Yargitay 11 HD, E 2016/1240 K 2017/3660, 13.06.2017; Yargitay 11 HD, E 2017/4709 K 2019/1565, 26.02.2019; Yargitay 11 HD, E 2016/7187 K 2018/4432, 08.06.2018; Yargitay 11 HD, E 2015/1744 K 2016/317, 14.01.2016 <https://www.kazanci.com.tr/> Erişim Tarihi 26 Temmuz 2021. AlmTK $\$ 435$ bakımından bkz Merkt (n 37) HGB $\$ 435$ N 1; CMR m. 32 bakımından bkz Sutter (n 8) 326; Klett, Schaden (n 17) 133.

156 'Mahkemece, davacının, zararın davalının... pervasızca bir davranışından meydana geldiğini ileri sürmediği, bu nedenle zikredilen yasa hükmünün somut olaya uygulanamayacağı sonucuna ulaşılmışsa da, ...Maddi olguya ilişkin iddianın bu biçimdeki ileri sürülüşünün, davalı taşıyıcının pervasızca hareket etmesi nedeniyle hasarın oluştuğuna ilişkin olduğunda duraksanmamalıdır' (Yargitay 11 HD, E 2018/3164 K 2019/4721, 24.06.2019 <https://www.kazanci.com.tr/> Erişim Tarihi 26 Temmuz 2021. İstanbul 14 BAM, E 2018/1237 K 2019/1183, 26.09.2019; İstanbul 14 BAM, E 2017/876 K 2018/295, 26/03/2018: 'Bu durumda somut olayın oluşşeklinin, bu yasal düzenlemeye göre değerlendirilmesi gerekir' <https://emsal.uyap.gov.tr/BilgiBankasiIstemciWeb/> Erişim Tarihi 26 Temmuz 2021.

157 Yargitay 11 HD, E 2007/12693 K 2009/7793, 25.6.2009 <https://www.kazanci.com.tr/> Erişim Tarihi 26 Temmuz 2021; İstanbul 12 BAM, E 2018/646 K 2019/1675, 31.12.2019 <https://emsal.uyap.gov.tr/BilgiBankasiIstemciWeb/> Erişim Tarihi 26 Temmuz 2021. 
göz ardı ettiği ağır ihmal niteliğindeki davranışlar bakımından söz konusu olur. Yükün güvenliği bakımından hangi güvenlik önlemlerinin alınması gerektiği, somut olayın şartlarına göre belirlenir.

Zarar doğacağı bilinci sübjektif bir olgudur, bu sebeple işaretlerden, emarelerden ve somut olayın özelliklerinden yola çıkılarak tespit edilir. Olayda vuku bulan pervasızca davranış, zararın muhtemelen meydana geleceğine ilişkin bir öngörüyü faile dayatıyorsa ikinci unsurun mevcut olduğu ve pervasızca davranış kusurunun şartlarının bir bütün olarak gerçekleștiği kabul edilir. Zararın muhtemelen meydana gelecek olması, zarar olasılığının galip ihtimal olması (yüzde elli bir ve üzerinde bir olasılık) anlamına gelir. Değerlendirmede olayların tipik akışı ve hayat tecrübeleri dikkate alınır. Taşıyıcının somut olayda fiilen gerçekleşen zararı nicelik ve nitelik yönünden de öngörmüş olması aranmaz.

Pervasızca davranış kusuru, olası kasta nazaran daha hafiftir. Taşıyıcının öngördüğü zararı kabul etmesi, bir başka anlatımla dolaylı da olsa istemesi gerekli olmadığı için pervasızca davranış kusurunun olası kasıt olarak değerlendirilmesi mümkün değildir. Bununla birlikte, pervasızca davranış kusuru ancak ağır ihmal niteliğindeki fiiller bakımından söz konusu olur. O halde hafif ihmal düzeyinde kalan fiiller, taşıyıcının sınırsız sorumlu tutulması için yeterli görülmemelidir. TTK m. 886'da aranan zarar bilinci sebebiyle, özen yükümlülüğünü ağır bir şekilde ihlal eden taşıyıcının bu davranış neticesinde muhtemelen bir zarar doğacağının da bilincinde olması gerekir. Bu yönden zarar bilinci taşımayan ağır ihmal niteliğindeki davranışlar da maddede aranan şartları sağlamaz. Dolayısıyla sınırsız sorumluluğun şartları, sadece ağır ihmalin yeterli görüldüğü 6762 sayılı TTK dönemine nazaran ağırlaştırılmıştır.

Pervasızca davranış kusuru bakımından taşıyıcıda, 'zararın muhtemelen meydana geleceğine ilişkin bilincin' bulunması aranır. Burada zarar doğması riskinin muhtemel olup olmadığına bakılır ve bundan kasıt galip ihtimaldir. Bilinçli ihmalin geleneksel kullanımında failin öngördüğü hukuka aykırı sonucun doğması ihtimalinin yüksek olması aranmaz; fiilin hukuka aykırı sonuç verebileceği ihtimalinin/olasıllğının öngörülmüş olması yeterlidir. Bu açıdan pervasızca davranış kusuru, bilinçli ihmalin geleneksel tanımı ile birebir uyuşmaz. Ancak muhtemel zarara ilişkin bilinç ve pervasızca davranışın ağır ihmal mahiyetinde olması sebebiyle pervasızca davranış kusurunun 'yeni bir bilinçli ağı ihmal' olarak nitelendirilmesi mümkündür. Bu nedenle geleneksel kusur ayrımında 'bilinçli ağır ihmal, 'i) basit bilinçli ağır ihmal' ve 'ii) pervasızca davranış kusuru' şeklinde iki alt başlığa ayrılabilir. Bu kusur türü, olası kasıt ağırlığına ulaşmayan 'yeni bir bilinçli ağır ihmal' türüdür.

Görüldüğü üzere öngörülen yeni kusur türü, hukukumuzda mevcut olan kusur ayrımlarından hiçbiri ile tam olarak örtüşmemektedir. Bu yönden içeriğinin TTK m. 886'da yer alan unsurlar ışı̆̆ında belirlenmesi gerekir. CMR m. 29 bakımından kasta eş değer kusurun belirlenmesinde de TTK m. 886'da öngörülen bu yeni kusur derecesi dikkate alınmalıdır.

Konu ile ilgili Yargıtay ve BAM kararlarında, pervasızca davranış kusuru için ya ağır kusur ifadesinin kullanıldığı ya da doğrudan Kanun'da geçen ifadenin metne yazıldığı görülmektedir. Ağır kusur genellikle ağır ihmali ifade etmek üzere kullanılır. Pervasızca davranış kusuru, failin zararın muhtemelen meydana geleceği bilinciyle işlediği ağır ihmal niteliğindeki fiiller bakımından söz 
konusu olur. Bu nedenle zarar bilinci taşımayan ve ağır ihmal düzeyinde kalan fiiller, TTK m. 886'da yer alan yeni kusur derecesi bakımında yeterli olmaz. Bu nitelendirme dışında, pervasızca davranış kusurunun unsurlarının ayrıntılı olarak ortaya konulduğu bir yargı kararı tespit edilememiştir.

\section{KAYNAKÇA}

Adıgüzel B, 'Eşya Taşımalarında Taşıyıcı Yardımcısı Kavramı ve Yardımcıların Taşıyıcının Sorumluluğuna Etkisi’ (2008) 3(2) Erzincan Üniversitesi Hukuk Fakültesi Dergisi 291-332.

Adıgüzel B, 'Yargıtay Kararlarında CMR m. 29'daki Kasta Eşdeğer Kusur Kavramının Yorumlanması' iç Başak Şit (ed), Ticaret Hukuku ve Yargitay Kararları Sempozyumu XXIV 10-11 Aralık (Banka ve Ticaret Hukuku Enstitüsü 2010) 353-377.

Adıgüzel B, 'Yeni Türk Ticaret Kanunu’nda Eşya Taşıma Hukuku Alanında Getirilen Yenilikler' (2012) 18(2) Marmara Üniversitesi Hukuk Fakültesi Hukuk Araştırmaları Dergisi 769-791.

Adıgüzel B, Karayoluyla Yapılan Taşımalarda Taşıyıcının Zıya ve Hasardan Doğan Sorumluluğu (2. Baskı, Adalet 2012).

Adıgüzel B, Taşıma Hukuku Deniz Ticareti Hariç (3. Bası, Adalet 2020).

Akıncı Z, Karayolu ile Milletlerarası Eşya Taşımacılı̆̆ı ve CMR (2. Bası, Seçkin 1999).

Arkan S, 'CMR Hükümlerine Göre Yardımcıların Fiillerinden Doğan Sorumluluk' iç Mürsel Başgül ve Haluk Konuralp (edr), Prof. Dr. Yaşar Karayalçın’a 65. Yaş Armağanı (Türkiye İş Bankası Kültür Yayınları 1988) 319-337.

Arkan S, 'Karayolu ile Eşya Taşınmasına İlişkin Uluslararası Sözleşmenin Uygulanma Koşulları ve Taşıyıcının Sorumluluğunu Düzenleyen Hükümleri (TTK İle Karşılaştırmalı Bir İnceleme)' (1979) X(2) Banka ve Ticaret Hukuku Dergisi 397-414.

Atabek R, Eşya Taşıma Hukuku, (1. Bası, Sulhi Garan Matbaası 1960).

Aydın A, CMR’ye Göre Taşıyıcının Zıya, Hasar ve Gecikmeden Doğan Sorumluluğu (1. Bası, Arıkan 2006).

Aydoğan F, 'Taşıma Hukukuna İlişkin Güncel Bazı Kararların Değerlendirilmesi’ iç Abuzer Kendigelen, Nurgül Yıldız, İsmail Cem Soykan, Necdet Uzel ve Müge Evlek (edr), Yürürlüğünün 6. Yılında ve Yargıtay Kararları Işı̆̆ında Türk Ticaret Kanunu Sempozyumu (Tebliğler - Tartışmalar) 12 Ekim 2018 (On İki Levha 2018) 233-250.

Bahnsen KU, 'CMR Art. 29' in Detlev Joost and Lutz Strohn (eds), Handelsgesetzbuch Band 2 (3rd edn, C.H.BECK 2015).

Basedow J, 'Internationales Einheitsprivatrecht im Zeitalter der Globalisierung,' (2017) 81 Rabels Zeitschrift für ausländisches und internationales Privatrecht 1-31.

Birinci Uzun T, Uluslararası Hava Taşımalarında Taşıyıcının Sorumluluğu (3. Bası, Seçkin 2020).

Brehm R, 'OR Art. 41' in Heinz Hausheer and Hans Peter Walter (eds), Berner Kommentar, Die Entstehung durch unerlaubte Handlungen, Art. 41 - 61 OR, Schweizerisches Zivilgesetzbuch, Das Obligationenrecht (4th edn, Stämpfli 2013).

Can M, Türk Taşıma Hukukunun Genel Esasları Cilt I (1. Bası, İmaj 2017).

Clarke M, 'Wilful misconduct under English law', (2016) 21(4) Uniform Law Review, 574-576.

Congar HC, CMR ve Türk Ticaret Kanunu Hükümleri Uyarınca Karayolu Taşımacılı̆̆ında Taşıyıcının Sorumluluğu (1. Bası, Yetkin 2021). 
Cömert Varol G, Kara Yolunda Yapılan Eşya Taşımalarında Taşıyıcının 6102 Sayılı Türk Ticaret Kanunu ve CMR Konvansiyonu Kapsamında Kayıp veya Hasardan Kaynaklanan Sorumluluğu (1. Bası, On İki Levha 2020).

Çağa T, 'Enternasyonal Deniz Hususi Hukukunda Yeni Bazı Gelişmeler', (1977) 9(2) Banka ve Ticaret Hukuku Dergisi 289-324.

Çağlayan Aksoy P, Hukuka Aykırılık ve Ahlaka Aykırılık Unsurları Çerçevesinde Salt Malvarlığı Zararlarının Tazmini (1. Bası, On İki Levha 2016).

Çetingil E, 'Alman Deniz Ticareti Hukukunun 1986 Yılı Reformunda Taşıyanın Sorumluluğu ile İlgili Olarak Yapılan Değişiklikler', (1992) 16(4) Banka ve Ticaret Hukuku Dergisi 21-57.

Damar D, 'Die „Costa Concordia“ ist auf den Felsen aufgelaufen - auch das Recht auf Haftungsbeschränkung?' (2012) 8 Verbraucher und Recht-Zeitschrift für Wirtschafts - und Verbraucherrecht 287-294.

Damar D, 'Milletlerarası Taşıma Hukukunda "Wilful Misconduct" - Kavramın Tarihçesi ve Tercümesi' (2004) 24(1-2) Milletlerarası Hukuk ve Milletlerarası Özel Hukuk Bülteni 379-393.

Damar D, 'Neues türkisches Handels - und Transportrecht' (2013) 5 Transportrecht 171-191.

Damar D, Wilful Misconduct in International Transport Law (1st edn, Springer 2011).

Damar D ve Yetiş Şamlı K, Milletlerarası Taşıma Hukuku’nda ve Yeni Türk Ticaret Kanunu’nda "Pervasızca Hareket" (Wilful Misconduct) Kusuru, (1. Bası, Deniz Hukuku Derneği-Sigorta Hukuku Derneği 2012).

Erbe S, 'Vertragliche Steuerung des Haftungsrisikos bei Transportverträgen' in Barbara Klett and Andreas Furrer (eds), Schaden im Warentransport Vertragsgestaltung - Versicherung - Schadenersatz (Schulthess 2016) 51-79.

Erdoğan M, CMR ve TTK Kapsamında Taşıyıcının Eşyanın Hasarından Doğan Sorumluluğu (1. Bası, On İki Levha 2020).

Erdil E, Karayolu ile Uluslararası Eşya Taşıma Hukuku (3. Bası, Seçkin 2020).

Eren F, Borçlar Hukuku Genel Hükümler (21. Bası, Yetkin 2017).

Eriş G, Açıklamalı-Gerekçeli-İçtihatlı Taşıma Hukuku (6102 Sayılı Türk Ticaret Kanununa Göre) (1. Bası, Seçkin 2015).

Feyzioğlu FN, Borçlar Hukuku Genel Hükümler Cilt 1 (2. Bası, Fakülteler Matbaası 1976).

Fremuth F, 'Haftungsbegrenzungen und deren Durchbrechung im allgemeinen deutschen Frachtrecht und nach der CMR' (2004) 3 Transportrecht 99-104.

Gençtürk M ve Yiğit İ, 'CMR Kapsamındaki Taşımalarda Taşıyıcının Sınırlı Sorumluluktan Yararlanamayacağı Haller' (2013) 3 Gaziosmanpaşa Bilimsel Araştırma Dergisi 34-46.

Gençtürk M, 'Yeni Türk Ticaret Kanununa Göre Taşıyıcının Sınırsız Sorumluluğunu Gerektiren Ağır Kusurları ve Türk Mahkemelerinin CMR'yi Uygulaması Bakımdan Muhtemel Etkisi' (2012) XIV(4) Gazi Üniversitesi Hukuk Fakültesi Dergisi 117-148.

Gençtürk M, Uluslararası Eşya Taşıma Hukuku (Gecikmeden Doğan Sorumluluk) (1. Bası, Vedat 2006).

Grosz M and von Ziegler A, 'CMR Art. 29' in Willi Fischer and Thierry Luterbacher (eds), Haftpflichtkommentar Kommentar zu den schweizerischen Haftpflichtbestimmungen (1st edn, Dike 2016).

Gürpınar D, Sözleşme Dışı Yanlış Tavsiyede Bulunma, Öğüt veya Bilgi Vermeden Doğan Hukuki Sorumluluk (1. Bas1, Güncel 2006).

Haak K, 'Haftungsbegrenzung und ihre Durchbrechung nach der CMR in den Niederlanden' (2004) 3 Transportrecht 104-107.

Hatemi H, Kocayusufpaşaoğlu N, Serozan R ve Arpacı A, Borçlar Hukuku Genel Bölüm Cilt 2 (2. Bası, Filiz 1998). 
Herber R, 'Die Neuregelung des deutschen Transportrechts' (1998) Neue Juristische Wochenschrift 3297-3308. Neumann H, 'Die unbeschränkte Haftung des Frachtführers nach $₫ 435$ HGB’ (2002) 11(12) Transportrecht 413-421.

Honsell H, Isenring B and Kessler MA, Schweizerisches Haftpflichtrecht (5th edn, Schulthess 2013).

İmre Z, Doktrinde ve Türk Hukukunda Kusursuz Mesuliyet Halleri (1. Bas1, İsmail Akgün Matbaas1 1949).

Jesser-Huß H, 'CMR Art. 29' in Karsten Schmidt (ed), Münchener Kommentar zum Handelsgesetzbuch Band 7 (4th edn, C.H.BECK 2020).

Kahraman Z, 'Medeni Hukuk Bakımından Pervasızca Hareket' iç Saibe Oktay Özdemir, Azra Arkan Serim ve Atilla Altop (edr), Prof. Dr. Sermet Akman’a Armağan (Filiz Kitabevi 2020) 405-427.

Kapancı KB, Ahlaka Aykırı Bir Fiille Kasten Verilen Zararın Tazmini (1. Bas1, Vedat 2016).

Karan H, Kara Ö ve Varan İ, Uluslararası Eşya Taşıma Sözleşmesi Hakkında Konvansiyon CMR Şerhi (2. Bası, Yetkin 2020).

Kaya A, 'Taşıyıcının Kara Yolu ile Eşya Taşımasına İlişkin Uluslararası Sözleşme’de (CMR) Öngörülen Sorumluluğunun Esasları (II)’ (1998) 56(1-4) İstanbul Üniversitesi Hukuk Fakültesi Mecmuası 239-267.

Kendigelen A ve Aydın A, 'Karayolu ile Uluslararası Eşya Taşıma Sözleşmesine İlişkin Antlaşma (CMR), Resmi Çeviriye İlişkin Sorunlar ve Bir Serbest Çeviri Denemesi’ iç Hayri Domaniç, Oğuz İmregün, Erdoğan Moroğlu ve Abuzer Kendigelen (edr), Prof. Dr. Ömer Teoman’a 55. Yaş Günü Armağanı Cilt 1 (Beta 2002) 495-525.

Kılıçoğlu AM, Borçlar Hukuku Genel Hükümler (21. Bası, Turhan 2017).

Kirchhof G, 'HGB $\$ 435$ ' in Martin Häublein and Roland Hoffmann-Theinert (eds), Beck'sche OnlineKommentare HGB (27. Edition, 15.1.2020).

Klett B, 'Die Haftung im internationalen Strassengüterverkehr nach CMR' (2017) 1 Strassenverkehr 20-29.

Klett B, 'Haftung im Strassengüterverkehr' in Barbara Klett and Andreas Furrer (eds), Schaden im Warentransport Vertragsgestaltung - Versicherung - Schadenersatz (Schulthess 2016) 111-143.

Koller I, 'HGB $₫ 435$ ’ in Ingo Koller, Peter Kindler, Wulf-Henning Roth, Klaus-Dieter Drüen and Nina Bach (eds), Handelsgesetzbuch (9th edn, C.H.BECK 2019).

Koller I, Transportrecht (9 th edn, C.H.BECK 2016).

Laimer S, 'Internationaler Gütertransport auf der Strasse zwischen Einheitsprivatrecht und Kollisionsrecht' in Susan Emmenegger, Stephanie Hrubesch-Millauer, Frédéric Krauskopf and Stephan Wolf (eds), Brücken bauen Festschrift für Thomas Koller (Stämpfli 2018) 485-498.

Merkt H, 'HGB $₫ 435$ ' in Baumbach Adolf and Klaus J. Hopt (eds), Handelsgesetzbuch (39th edn, C.H.BECK 2020).

Nomer HN, Borçlar Hukuku Genel Hükümler (14. Bası, Beta 2015).

Oftinger K and Stark EW, Schweizerisches Haftpflichtrecht, Erster Band: Allgemeiner Teil (5th edn, Schulthess 1995).

Oğuzman MK ve Öz MT, Borçlar Hukuku Genel Hükümler Cilt II (13. Bası, Vedat 2017).

Orbay Ortaç N, 'Havayolu ile Taşımalarda Bagajın Zıyaı veya Hasara Uğraması Nedeniyle Doğan Akdi Sorumluluk' (2014) 114 Türkiye Barolar Birliği Dergisi 143-178.

Otte K, 'CMR Art. 29' in Franco Ferrari, Eva-Maria Kieninger, Peter Mankowski, Karsten Otte, Ingo Saenger, Götz Schulze und Ansgar Staudinger (eds), Internationales Vertragsrecht (3rd edn, C.H.BECK 2018).

Özdemir A, Hava Taşıyıcısının Sorumluluğu (1. Bası, Sanem Matbaacılık 1992).

Özdemir T, Uluslararası Eşya Taşıma Hukuku (Zıya ve/veya Hasar Sorumluluğu) (1. Bası, Vedat 2006).

Paschke M, 'HGB $₫ 435$ ' in Hartmut Oetker (ed), Handelsgesetzbuch (6th edn, C.H.BECK 2019). 
Ramming K, Hamburger Handbuch Multimodaler Transport (1st edn, C.H.BECK 2011).

Wolfgang Schaffert, 'HGB $₫ 435$ ' in Detlev Joost and Lutz Strohn (eds), Handelsgesetzbuch Band 2 (3rd edn, C.H.BECK 2015).

Sekmen O, TKHK Kapsamında Karayoluyla Eşya Taşımasında Zıya, Hasar ve Gecikmeden Doğan Tazminat (1. Bas1, Aristo 2020).

Sözer B, ‘Türk Sivil Havacılık Kanunu’nun Hükümlerine Göre Taşıyanın ve İşletenin Sorumluluğu’ (1984) 12(4) Banka ve Ticaret Hukuku Dergisi 3-86.

Sözer B, Türk Hukuku’nda ve Uluslararası Hukuk’ta Havayolu ile Yük Taşıma Sözleşmesi (2. Bası, Vedat 2009).

Sözer B, Deniz Ticareti Hukuku Cilt 1 (5. Bas1, Vedat 2019).

Sutter R, 'Besteht eine Darlegungspflicht des angegriffenen Frachtführers beim Verschuldensnachweis? Betrachtungen zum internationalen und schweizerischen Frachtrecht' (2010) 3 Aktuelle Juristische Praxis 325-332.

Süzel C, Navlun Sözleşmesinden Doğan Sorumluluğun Sinırlandırılması (1. Bası, On İki Levha 2021).

Tandoğan H, Türk Mes’uliyet Hukuku (Akit Dışı ve Akdî Mes’uliyet) (2. Bası, Vedat 2010).

Tekinay SS, Akman S, Burcuoğlu H ve Altop A, Tekinay Borçlar Hukuku Genel Hükümler (7. Bası, Filiz 1993).

Thume KH, ‘60 Jahre CMR Art. 29 - Zankapfel damals wie heute’ (2017) 4 Transportrecht 141-196.

Thume KH, 'HGB $\$ 435$ ’ in Karsten Schmidt (ed), Münchener Kommentar zum Handelsgesetzbuch (4th edn, C.H.BECK 2020).

Thume KH, 'Durchbrechung der Haftungsbeschränkung nach $₫ 435$ HGB im internationalen Vergleich' (2002) 1 Transportrecht 1-7.

Uslu M, CMR Hükümleri Çerçevesinde Taşıyıcının Gecikmeden Doğan Sorumluluğu (1. Bası, Seçkin 2010).

Ülgen H, Hava Taşıma Sözleşmesi (1. Bası, Banka ve Ticaret Hukuku Enstitüsü 1987).

von Tuhr A and Peter H, Allgemeiner Teil des Schweizerischen Obligationenrechts Band I (3rd edn Schulthess 1984).

Wojtek R and Krug JA, 'Haftungsvermeidung im Transportgewerbe' in Christoph E. Hauschka, Klaus Moosmayer and Thomas Lösler (eds), Corporate Compliance Handbuch der Haftungsvermeidung im Unternehmen (3rd edn, C.H.BECK 2016).

Yavaş A, 'Kara Yolunda Yapılan Yük Taşımasında Sınırlı Sorumluluktan Yararlanma Hakkının Kaybına Sebebiyet Veren Kusur Türlerinin Değerlendirilmesi' (2017) 2(Ocak) Yeditepe Üniversitesi Hukuk Fakültesi Dergisi 200-238.

Yavaş A, Kara Yolunda Konteyner ile Yapılan Yük Taşımasında Kayıp veya Hasardan Doğan Sorumluluk (1. Bası, On İki Levha 2016).

Yazıcıoğlu E, Hamburg Kurallarina Göre Taşıyanın Sorumluluğu (1. Bası, Beta 2000).

Yetiş Şamlı K, 6102 Sayılı Türk Ticaret Kanunu’na Göre Taşıyanın Zıya Hasar ve Geç Teslimden Sorumluluğu (2. Bası, On İki Levha 2013).

Yetiş Şamlı K, Uluslararası Kara, Hava ve Deniz Yoluyla Eşya Taşımalarında Taşıyıcının/Taşıyanın Sinırlı Sorumluluktan Yararlanma Hakkının Kaybı (1. Bası, On İki Levha 2008).

Yeşilova E, Taşıyııının CMR Hükümlerine Göre Yardımcı Şahıslarının ve Müteakip Taşıyıcıların Eylemlerinden Doğan Sorumluluğu (1. Bası, Yetkin 2004).

Yıldız Ş, 'TTK Hükümleri Işığında Taşıyıcının (Kara Yoluyla) Eşya Taşımadan Doğan Sorumluluğu' (2015/2) 14(28) İstanbul Ticaret Üniversitesi Sosyal Bilimler Dergisi 97-109.

Yüce AA, 'CMR ve TTK'da Taşıyıcının Sorumluluğu ile Kast ve Kasta Eşdeğer Kusurun Sorumluluğa Etkisi' (2012) 3-4(Aralık-Ocak) Erzincan Üniversitesi Hukuk Fakültesi Dergisi 171-195. 